\title{
Rewizja komór celnych i stacji mytniczych województwa kaliskiego z 1571 r. Edycja Aktu rewizorów ziemskich ${ }^{*}$
}

Zarys treści: Tekst przedstawia edycję rewizji komór celnych oraz stacji mytniczych z obszaru województwa kaliskiego z 1571 roku. Wydawana rewizja powstała na mocy ustawy sejmu lubelskiego z 1569 r., na którym to postanowiono m.in. uzupełnić wyniki lustracji przeprowadzonej w połowie lat sześćdziesiątych XVI w. Akt rewizorów ziemskich województwa kaliskiego jest źródłem znanym historykom od czasów Karola Buczka, który pisał o nim we wstępie do edycji lustracji dróg wydanej przez Bożenę Wyrozumską. Źródło przechowywane jest obecnie w Archiwum Głównym Akt Dawnych, razem z innymi materiałami lustracyjnymi. Ma ono charakter czystopisu, zawierającego wiele informacji o stanie gościńców, uwarunkowań środowiskowych czy też stosunków sąsiedzkich pomiędzy szlachtą omawianego terytorium. Wydawany akt rewizorów zawiera liczne kopie wcześniejszych przywilejów, zezwalających na pobór ceł lub myta w wymienianych miejscowościach.

Abstract: A presentation of an edition of an inspection of customs houses and tollgates in the voivodeship of Kalisz (1571). The published inspection was the outcome of a constitution passed by the Sejm of Lublin in 1569, which resolved, i.a. to supplement the results of an inspection conducted in the mid-1560s. Akt rewizorów ziemskich województwa kaliskiego has been a source familiar to historians from the time of Karol Buczek, who wrote about it in an introduction to an edition of a road inspection issued by Bożena Wyrozumska. A present the source is kept in the Central Archives of Historical Records in Warsaw together with other lustration material. This clean copy contains numerous information about the state of roads, environmental conditions, and neighbourly relations between members of the gentry in the discussed territory. The published inspectors' document includes numerous copies of earlier privileges consenting to the collection of customs duties or tolls in the mentioned localities.

Słowa kluczowe: geografia historyczna, komory celne, stacje mytnicze, województwo kaliskie w XVI w., sieć drogowa.

Keywords: historical geography, custom houses, tollgates, Kalisz voivodeship in the 16th century, roads system.

Wydawana rewizja z terenu XVI-wiecznego województwa kaliskiego jest źródłem znanym historykom od kilkudziesięciu latt ${ }^{1}$. Pierwszy pisał o niej Karol Buczek we wstępie do edycji lustracji dróg

\footnotetext{
* Tekst powstał na marginesie projektu „Atlas historyczny Polski: Wielkopolska w drugiej połowie XVI w.” (NPRH, nr 11H11004080), realizowanego przez zespół Zakładu Atlasu Historycznego w Instytucie Historii PAN pod kierunkiem prof. Marka Słonia w latach 2012-2016. Publikowana edycja nie miałaby obecnego kształtu, gdyby nie krytyczne uwagi oraz istotne sugestie, które otrzymałem od pana Henryka Rutkowskiego, za co chciałbym Mu w tym miejscu serdecznie podziękować.

${ }^{1}$ Odnośnie systemu celnego i mytniczego w dawnej Polsce zob. R. Rybarski, Handel i polityka handlowa Polski w XVI stuleciu, t. 1: Rozwój handlu polityki handlowej, Poznań 1928, s. 295-313; A. Manikowski, J. Łukasiewicz, M. Kaliszuk,
} 
województwa krakowskiego z 1570 r., przygotowanej przez Bożenę Wyrozumskąa². W późniejszych latach była ona natomiast wykorzystywana jako jedno ze źródeł przy opracowaniu hasła dotyczącego Noteci w Słowniku historyczno-geograficznym województwa poznańskiego w średniowieczủ. Dokument ten nie cieszył się jednak dobrą opinią. Wspomniany Karol Buczek stwierdził nawet, że „«rewizorzy ziemscy» kaliscy nie wysilali się zbytnio, poprzestali bowiem na oglądnięciu zaledwie 31 myt, które albo już były skontrolowane w r. 1564, albo zostały im wskazane przez miejscowe czynniki”. Pisał także, że „Stosując się do konstytucji sejmu 1569 r. mierzyli [rewizorzy — TZ] w razie potrzeby drogi i niekiedy kazali «obwoływać» ich poszerzenie, ale tylko w miejscach, gdzie pobierano myta, samych dróg natomiast nie opisywali. Bardziej «po łebkach» zadania swego wypełnić też chyba nie mogli"'s.

Dziś można uznać, że opinia Buczka była zbyt surowa, gdyż myta i komory celne wymienione w tekście źródłowym nie znajdują w zdecydowanej większości potwierdzenia w zachowanych lustracjach wielkopolskich królewszczyzn z lat $1564-1620^{6}$. Fakt ten można po części tłumaczyć tym, że spośród miejscowości wymienionych w źródle dwadzieścia dwie były we władaniu szlachty, dziewięć stanowiło własność monarszą ${ }^{7}$, zaś tylko trzy należały do uposażenia kościelnego ${ }^{8}$. Niestety nie wiadomo ile miejsc, w których pobierano opłaty, nie zostało wymienionych w źródle. Istnieją jednak pewne przesłanki, które mogą sugerować, że mamy do czynienia ze zdecydowaną większością tych obiektów. Mogą o tym przekonywać — z jednej strony — wywiad przeprowadzony wśród mieszkańców województwa podczas dokonywania rewizji ${ }^{9}$, z drugiej zaś — sam dobór urzędników, wśród których znaleźli się podkomorzy, chorąży i wojski. Byli oni związani bezpośrednio z funkcjonowaniem terenowego aparatu sądowego w województwie — sądu podkomorskiego i organizowaniem pospolitego ruszenia. Naturalnie nie można mieć w tym względzie stuprocentowej pewności, natomiast można zakładać, że lustracja myt i punktów poboru cła była przeprowadzona, na tyle, na ile pozwoliły na to warunki, w sposób możliwie najpełniejszy. Dodatkowo należy zwrócić uwagę na to, że wspomniani wyżej urzędnicy nie dysponowali żadnymi materiałami skarbowymi, jak na przykład

Cło, w: Encyklopedia historii gospodarczej Polski do 1945, t. 1, red. A. Mączak, Warszawa 1981, s. 103-105; S. Russocki, Myto, w: tamże, s. 572. Warto zwrócić także uwagę na rolę dochodów z ceł jako części uposażenia urzędników ziemskich w Koronie w: W. Pałucki, Studia nad uposażeniem urzędników ziemskich w Koronie do schyłku XVI wieku, Warszawa 1962, s. $16-18,62-82$.

${ }^{2}$ K. Buczek, Wstęp historyczny, w: Lustracja dróg województwa krakowskiego z roku 1570, wyd. B. Wyrozumska, wstęp historyczny K. Buczek, Wrocław-Warszawa-Kraków 1971 [dalej: LDK], s. XVI. Źródło znajduje się w AGAD, Metryka Koronna, dz. XVIII Lustracje, sygn. 4, k. 300-309 [dalej: Akt Rew.].

${ }^{3}$ K. Górska-Gołaska, Noteś w: Słownik historyczno-geograficzny województwa poznańskiego w średniowieczu, oprac. K. Górska-Gołaska, T. Jurek, J. Luciński, G. Rutkowska, I. Skierska, red. A. Gąsiorowski, cz. 3, z. 2, Poznań 1995, s. 312-317.

${ }^{4}$ LDK, s. XVI.

5 Tamże.

${ }^{6}$ Por. Volumina constitutionum [dalej: VC], oprac. S. Grodziski, I. Dwornicka, W. Uruszczak, t. 2, vol. 1: 1550-1585, Warszawa 2005, s. 250: „Naznaczamy też do wszystkich woiewodztw rewizory, tych trzech urzędnikow ziemskich: podkomorzego, chorążego a wojskiego, aby ci rewidowali w swych ziemiach i powieciech wszystkie cła, myta, grobelne i mostowe, nadane po śmierci krola Władysława, ktore ieszcze nie są rewidowane i dostatecznie miejsca ich mają opisać, a to Nam na przyszły sejm przynieść, aby się tam kognicyja stąd i decyzyją stała, ktore potrzebnemi są i ostać się mają, wedle statutu krola Zygmunta sławnej pamięci. A ktore iako szkodliwe ostać się nie mogą, iakoż zniesionemi są, a te ktore są rewidowane dostatecznie, ad cognitionem na przeszły sejm odkładamy. Ciż lustratorowie gościńce spisać mają i drogę im na dziesięć łokci, dla furmanow i pędzenia wołów wymierzyć. A jeśliby komu przywilej zginął stary, ktoryby był w Warszawie ukazowany i approbowany, kancellaryja inny wedle kontenta approbacyi, takiemu każdemu wydać powinna będzie”.

${ }^{7}$ Nakło, Kcynia, Konin, Pyzdry, Powidz, Stawiszyn, Koło i Kalisz.

8 Trzemeszno, Ślesin i Ołobok.

9 Akt Rew., 302v: „W Łabiszynie jest młyn na Notesi rzece, u którego przez groblą jeżdżą, od który [s], jako nam urzędnik z burmistrzem i z radą sprawę dali, cła bierzą, na co jednak oryginału nie ukazano”; tamże, k. 303v: „Tusmy [w Siejuszycach - TZ] widzieli list króla Zygmunta, który, aprobacyją dając, referuje się do jakiegoś oryginału starego. Aprobacyją dano w Piotrkowie feria secunda ante Purificationis Mariae [30 I] 1525, ale w niej nie opisano po czemu brać. Widzielismy za tym mostek na miejscu suchym i przetoż się nam zda cło niepotrzebne”. 
inwentarze czy listy komór celnych oraz stacji mytniczych ${ }^{10}$. Podobnie jak w wypadku lustracji królewszczyzn duże znaczenie miały informacje ustne ${ }^{11}$.

Fundamentalne znaczenie dla zrozumienia roli Aktu rewizorów, a także próby przeprowadzenia jego wewnętrznej krytyki ma analiza rozmieszczenia komór i punktów poboru myta na mapie XVI-wiecznego województwa kaliskiego, gdyż dane te mogą służyć zarówno do badań nad dawnym handlem, jak również stanowią doskonały materiał, pozwalający na prowadzenie prac nad siecią drogową wczesnonowożytnej Polski ${ }^{12}$. W literaturze historycznej powszechnie przyjmuje się, że obiekty te tworzyły z gościńcami oraz jarmarkami skomplikowany system naczyń połączonych. Rozmieszczenie geograficzne kaliskich komór celnych i stacji mytniczych zależne było od przebiegu najważniejszych traktów handlowych na linii Pomorze-Śląsk i Ruś-Śląsk ${ }^{13}$. Najwięcej z nich było usytuowanych w powiatach konińskim, kaliskim oraz pyzdrskim, co może sugerować, że były to tereny najważniejszego tranzytu wołami, jak i innymi dobrami ${ }^{14}$. W podobnym wymiarze źródło podaje informacje o stanie poszczególnych dróg ${ }^{15}$, zmianie ich przebiegu w zależności od pory roku ${ }^{16}$ czy istniejących sporów międzyludzkich ${ }^{17}$. Bardzo ważną informacją jest także określenie pewnej hierarchii związa-

${ }^{10}$ Lustracja województw wielkopolskich i kujawskich 1564-1565, t. 1, wyd. A. Tomczak, Cz. Ohryzko-Włodarska, J. Włodarczyk, Warszawa 1961, s. XVI.

${ }_{11}$ Tamże.

12 Poza publikacjami w serii „Atlas historyczny Polski. Mapy szczegółowe XVI wieku”, zob.: J. Nowakowa, Rozmieszczenie komór celnych i przebieg dróg handlowych na Ślasku do końca XIV wieku, Prace Wrocławskiego Towarzystwa Naukowego, Seria A, nr 43, Wrocław 1951, s. 15-21. Zupełnie inną opinię na temat przydatności komór celnych w tym procesie wyraził niegdyś Henryk Samsonowicz, Przemiany osi drożnych w Polsce późnego średniowiecza, Przegl. Hist., 64, 1973, z. 4, s. 705: „Wbrew zdaniu S. Weymana nie sądziłbym, że istniał bezpośredni związek komór celnych z siecią dróg głównych. Cło stanowiło ważne źródło dochodu, przeto starano się możliwie często usytuować komory celne. Liczba komór celnych in ambitu Cuyaviensis Ducatus przynależnych kościołowi wynosiła 15 na obszarze około $2500 \mathrm{~km}^{2}$, przy czym odległość jednej komory od drugiej wynosiła od 10 do $20 \mathrm{~km}$. Oczywiście, że na wszystkich drogach wielkiego handlu pobierano cła, ale pobierano je także i na szlakach drugorzędnych. Większość komór najpewniej pobierała zwyczajowe opłaty, często w towarze, od przewożonych artykułów codziennego użytku".

${ }_{13}$ Drogi przedstawione na mapie załączonej do artykułu wytyczono na podstawie jedynego do tej pory całościowego opracowania dróg w Wielkopolsce autorstwa Stefana Weymanna: S. Weymann, Ze studiów nad zagadnieniem dróg $w$ Wielkopolsce od X do XVIII wieku, „Przegląd Zachodni”, 9, 1953, z. 2, nr 6-8, s. 194-253. Autor ten nie zrekonstruował sieci drogowej północnych części województw poznańskiego (powiat wałecki) oraz kaliskiego (powiat nakielski), w związku z czym gościńce oraz poboczne trakty urywają się na linii Noteci. Podstawę kartograficzną przy wyrysowywaniu dołączonej do artykułu mapy (granice, powiaty, osadnictwo) stanowiły także dane przestrzenne XVI-wiecznej Korony, udostępnione na stronie „Atlas Źródeł i Materiałów do Dziejów Dawnej Polski”, <www.atlasfontium.pl> [dostęp 09.02.2016].

${ }^{14}$ M. Małowist, Wschód a Zachód Europy w XIII-XVI wieku, Warszawa 2006, s. 296-301; I. Blanchard, The Continental European Cattle Trades, 1400-1600, „The Economic History Review”, New Series, 39, 1986, z. 3, s. 437-441. Por. z przechowywanym w AGAD dokumentem: Spisanie jarmarków Wielkopolskich, to jest przed granicami śląskimi, także $i$ w Ślasku w miastach cesarskich i ksiązęcych, na których trzeba bywać pilności wielkiej — Zbiór Dokumentów Papierowych, nr 3780 i Z. Guldon, L. Stępkowski, Handel wołami w świetle rejestrów celnych komory kaliskiej z lat 1647-1654, Kwart. HKM, 26, 1978, z. 4, s. 537-542. Por. z niezachowanym już dziś tekstem: Opłaty i utrudnienia, jakie kupcy ponosić sq zniewoleni przy pędzeniu wołów od Łęczycy aż do granic państwa pod Międzyrzec, w: J. Leitgeber, Z dziejów handlu i kupiectwa poznańskiego za dawnej Rzeczypospolitej Polskiej, Poznań 1929, s. 146-150. Zob. także uwagi Janiny Nowakowej na temat rozmieszczenia geograficznego komór na średniowiecznym Śląsku, J. Nowakowa, Rozmieszczenie komór, s. 190-200. ${ }^{15}$ Akt Rew., k. 302v: „W Strzemesznie jest mostek zbudowany na gościńcu gnieźnieńskim, na złej drodze, i od tego cło bierzą [...]".

16 Tamże, k. 304v: „Jest tu gać naprawiona i przejazd, natenczas gdysmy oględowali dobry, ale nam sprawę dano, iż z wiosny bywa zły przejazd i dlategoż gać naprawują i cło bierzą po pieniądzu od konia”.

17 Tamże, k. 304: „Tu tędy, gdy dobrze naprawowano, kupcy jeżdżali a bierano od nich cła od wozu formańskiego i kupieckiego po czterzy pieniądze, a [od] konia albo wołu, kto do targu wiódł, brano od niego po pieniądzu za przywilejem Kazimirza pod datą 1457. Ale iż tego cła sąsiad Głębocki połowicę miał, prze niezgodę zaniechał naprawiać drogi na starym miejscu i dla tej ich niezgody, a nie naprawowania drogi i mostu, formani tamtędy już natenczas nie idą. A chocia się obrócili tamże od starego gościńca ćwierci mile, między Łagiewnikami a Bielewem, gdzie ten to Głębocki z Gosławskim zmówiwszy się, zabudowali inszy most, acz też nie dobry, wyprawiwszy sobie oba cło u króla Zygmunta 1530 i bierzą je. Jednak iż się szlachta niemało, która tam na tym ostrowie mieszka, skarży, że nie mogą do powiatu swego konińskiego przejeżdżać, zatym dawnego gościńca na Lubstowie spustoszeniem, kędy z dawna jeżdżali, zdało się nam to Waszej K[rólewskiej] 


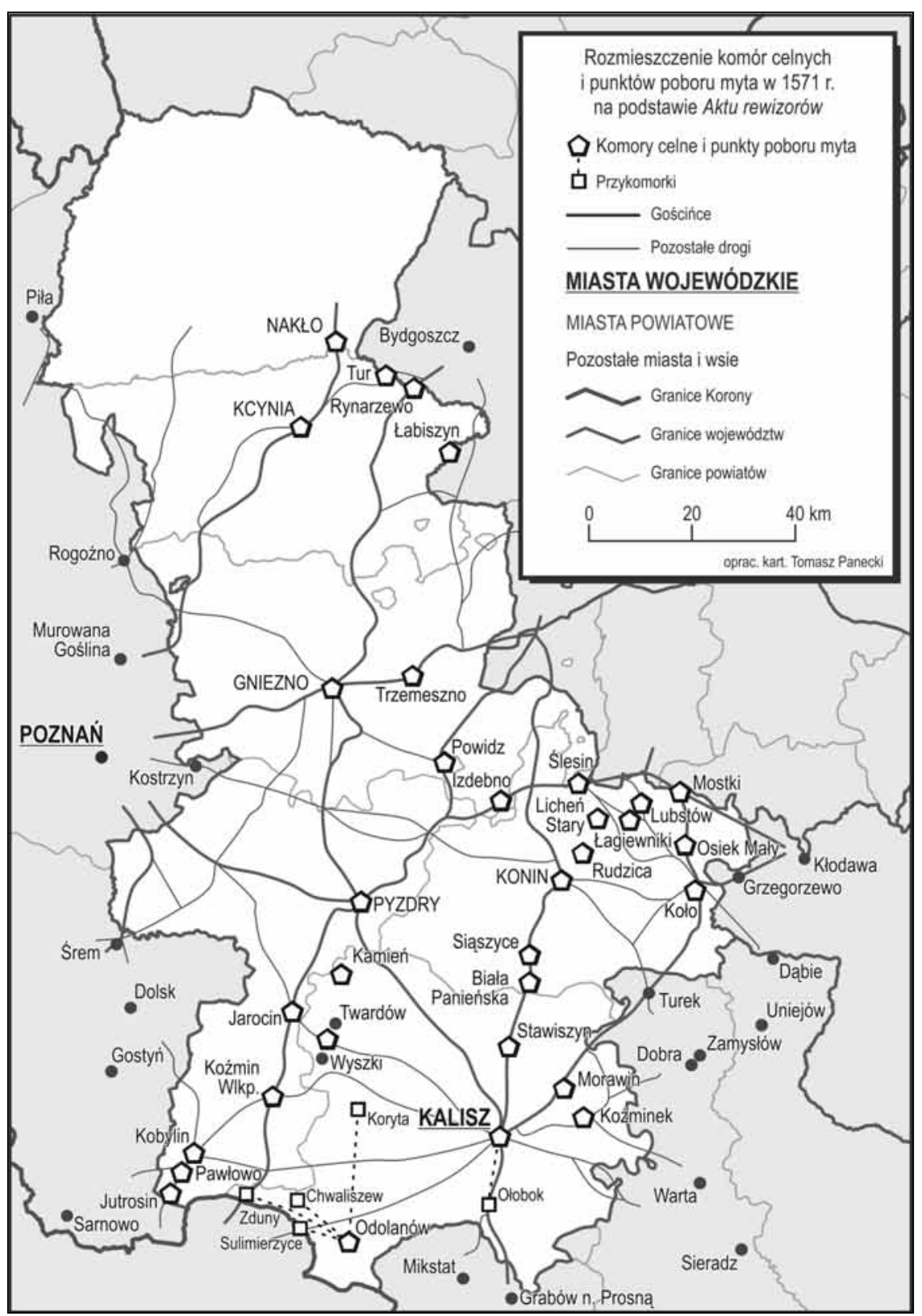

nej z funkcjonowaniem komory w Odolanowie. Akt rewizorów podaje, że cło ustanowione w tym mieście pobierane było także w okolicznych osadach, do których należały Sulmierzyce, Koryta, Zduny oraz Chwaliszewo ${ }^{18}$. Zapiska bardzo dobrze obrazuje mechanizm poboru opłat, w którym cło nadane królewskiemu miastu wybierane było nie w nim samym, ale w jego okolicy (w przykomorkach) tak, by niemożliwe było ominięcie danego ośrodka przez przejezdnych kupców ${ }^{19}$.

M[ości] naszemu miłościwemu panu przy tym oznajmić, ażeby to po staremu naprawowano, gdyż tego pospolity człowiek potrzebuje".

18 Tamże, k. 305v. Por. z AGAD, Zbiór Dokumentów Papierowych, nr 3780: „Pro Margarete [13 VII — TZ] jarmark w Gostyniu główny na woły. Tam trzeba pilnie się przypatrować na targowisku, a pisać gdzie, kto i skąd woły kupować będzie. Z tego Gostynia zajechać trzeba po komorach począwszy Sulmierzyce, Zduny, Jutrosin, Poniec, Wschowa, Kopanica, aż do Grójca, Zbąszyna dla przeliczenia wołów".

19 B. Wyrozumska, Drogi w ziemi krakowskiej do końca XVI wieku, Wrocław-Warszawa-Kraków 1977, s. 23. 
Jak pisałem już wyżej działania rewizorów województwa kaliskiego były zbliżone do wcześniejszych praktyk znanych z połowy lat sześćdziesiątych XVI w. Najpierw podawano do publicznej wiadomości informację o zbliżającej się lustracji, co poświadczać miały wpisy w powiatowych księgach sądowych ${ }^{20}$. W stosunku np. do lustracji dróg wydanej przez Bożenę Wyrozumską odczuwalny jest brak protestacji inserowanych do dokumentu lustracyjnego. $Z$ terenu województwa kaliskiego znamy tylko tę przygotowaną przez kasztelana biechowskiego Stanisława Wysockiego ${ }^{21}$. Wszystkie dokumenty okazywane rewizorom były skrupulatnie odnotowywane - wśród nich znalazły się także informacje o pozwoleniach na pobór cła pochodzące z XIII i XIV w.22

Karol Buczek datował powstanie rękopisu na okres od 20 IV 1571 aż do 7 VII 1572, z czego pierwsza data wynikała $\mathrm{z}$ dokumentu skopiowanego przez rewizorów ${ }^{23}$, drugą zaś wyznaczała śmierć Zygmunta Augusta ${ }^{24}$. Data ante quem może budzić pewne wątpliwości z powodu dosyć dużej zwłoki w stosunku do innych znanych materiałów. Buczek nie miał możliwości wykorzystania spisów urzędników, które jak się okazuje, mogą zawęzić moment powstania rękopisu do zdecydowanie krótszego czasu. Podstawą tej zmiany jest wzmianka o tym, że znany z lustracji chorąży kaliski Prokop Broniewski pełnił swój urząd od 1556 r. aż do 25 VI 1571, potem został mianowany podkomorzym poznańskim ${ }^{25}$. Tak samo w tekście źródła wymieniony jest kasztelan biechowski Stanisław Wysocki, który pełnił swój urząd do 20 VI 1571. Należałoby w takim razie przyjąć, że Akt rewizorów przechowywany w AGAD powstał — w formie jaką znam i wydaję — pomiędzy 20 IV 1571 a datą objęcia przez Wysockiego kasztelani lędzkiej, czyli 20 VI 1571. Datowanie rękopisu współgra także $\mathrm{z}$ informacjami o presji czasu, jaka wywierana była na lustratorów królewskich na sejmie $1570 \mathrm{r}$. w kwestii przeprowadzania lustracji ${ }^{26}$.

Lustracja ceł i myt województwa kaliskiego została zszyta z innymi luźnymi dokumentami, składającymi się na tom czwarty lustracji w XVIII. dziale Metryki Koronnej27. Tom ten składa się z ponad 450 kart oprawionych w półskórek. Daty graniczne tej kolekcji zawierają się w latach 1489-1742, z czego wiele z akt do niej włączonych to różnego rodzaju późniejsze (XVII- i XVIII-wieczne) wypisy z późnośredniowiecznych i wczesnonowożytnych źródeł. Bezpośrednio przed Aktem rewizorów znajdują się dyplomy dotyczące Wieliczki oraz Ciężkowic z lat 1496, 1489 i 1566 (k. 296-299v), po nich zaś wszyte są pozwy królewskie z obszaru całego państwa z 1549 r. (k. 310-335v). Zbiór zawiera także wiele inwentarzy, rewizji nadań oraz lustracji pojedynczych starostw. W wypadku wydawanego źródła mamy do czynienia z dobrze zachowanym oryginałem, będącym już opieczętowanym i podpisanym przez urzędników ziemskich biorących udział w objeździe województwa (il. 1). Poza wspominanym Broniewskim był to także Bartłomiej Suchorzewski, piastujący urząd podkomorzego

\footnotetext{
${ }^{20}$ Akt Rew., k. 302.

${ }_{21}$ Tamże, k. 307v.

${ }^{22}$ Takim przykładem może być Rynarzewo, w którym okazano urzędnikom dokument Władysława Łokietka inserowany w przywileju Zygmunta Starego z 1523 r., tamże, k. 302v.

${ }^{23}$ Tamże, k. 306: „U Jutrosina na Pawłowie bierzą cło nowe. Od każdego konia zaprzężonego po kwartniku, od Polaków i od Ślęzaków, gdy albo z Polski do Śląska, albo ze Śląska do Polski jadą. Dan na to przywilej od Waszej K[rólewskiej] M[ości] naszego miłościwego pana Varszoviae 20 Aprilis 1571”.

${ }^{24}$ LDK, s. XVI i przyp. 46, tamże.

${ }_{25}$ UdR. Spisy, t. 1, z. 2, s. 47.

${ }^{26}$ Zob. VC, s. 296: „Lustratorom na rewidowanie dobr Naszych krolewskich z sejmu przeszłego wysłane, gdyż tu rewizy na ten sejm nie odnieśli, rozkazujemy, aby regesta porządnie wszystkich prowentów spisali, na nowe lato w Rawie do rąk pana podskarbiego i deputatow oddali. A iż urzędnicy ziemscy wedle konstytucyi sejmu lubelskiego nie wszyscy rewidowali ceł, myt, grobelnych w powieciech swoich, przeto aby się tej konstytucyi dosyć działo rozkazujemy, żeby pod straceniem urzędów temu dosyć czynili, co na drugi sejm porzadnie spisawszy, odesłać abo odnieść będą powinni; o ktorą winę ad cuiuscunquam instantiam będą pozwani abo ieden pozwany ma przed Nami odpowiedać”; LDK, s. XVI.

${ }^{27}$ Skany dostępne są na stronie archiwum pod adresem $<$ http://www.agad.gov.pl/inwentarze/Metr_orx.xml\#series9> [dostęp: 13.02.2016].
} 


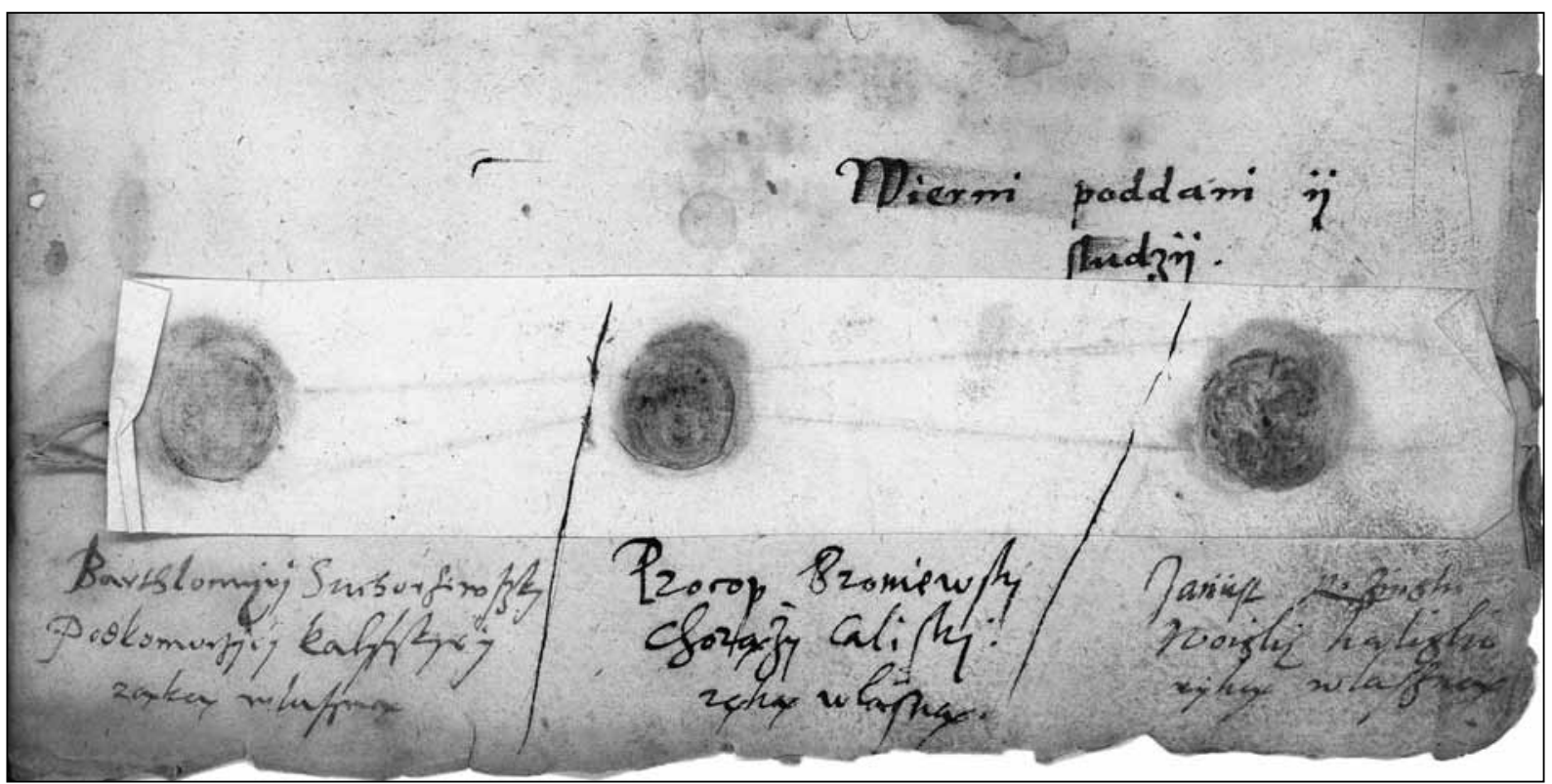

1. Własnoręczne podpisy urzędników ziemskich wraz z odciskami pieczętnymi, Akt Rew., k. 309

kaliskiego w latach 1565-1586 ${ }^{28}$ oraz wojski kaliski Janusz Rysiński, który pełnił tę godność w latach 1571-157729.

Podczas pracy edytorskiej korzystałem z instrukcji wydawniczej źródeł nowożytnych opracowanej przez zespół badaczy pod kierunkiem Kazimierza Lepszego opublikowanej w 1953 r. ${ }^{30}$ Pisownię rękopisu zmodernizowałem tak, by była zrozumiała dla dzisiejszego czytelnika. Zabieg ten wynika z faktu, że przedmiotem wydania nie jest źródło w swej filologicznej postaci, ale tekst wraz z jego całą warstwą informacyjną istotną z punktu widzenia historii skarbowości oraz geografii historycznej. $\mathrm{Z}$ tego też powodu zrezygnowałem $\mathrm{z}$ występujących w rękopisie nawiasów, pełniących funkcję znaków przestankowych — oddawałem je za pomocą zwykłych przecinków. Tak samo akapity tworzone przez pisarza oznaczałem w edycji wielokropkiem $\mathrm{z}$ adnotacją o pustym miejscu w rękopisie. Poczynione zabiegi edytorskie wynikają także z powodu łatwości dostępu do oryginalnego materiału, udostępnianego za pomocą strony internetowej AGAD. Zakładam, że szczególnie zainteresowany rękopisem Czytelnik będzie mógł do niego zajrzeć bez najmniejszych problemów i dokonać odpowiedniej weryfikacji zaproponowanej edycji. Dosyć ważną zmianą w stosunku do instrukcji Lepszego było każdorazowe informowanie Czytelnika o formie źródłowej wyrazów zapożyczonych z języka łacińskiego. Z tego np. względu - przykładowo - pojawiające się słowo constituciei (k. 302) sprowadziłem do formy konstytucyjej, natomiast oryginalny zapis słowa odnotowałem w przypisie rzeczowym.

Pismo źródła jest czytelne, słowa zawierają dosyć dużo światła pomiędzy poszczególnymi literami, w związku z czym odczyt nie sprawiał praktycznie żadnych problemów — tekst ma wyraźnie charakter czystopisu. Akt został spisany w całości przez tę samą nieznaną nam z imienia i nazwiska osobę, w większości w języku polskim. Po łacinie zapisywano jedynie wypisy pochodzące z okazywanych rewizorom przywilejów. Z tego też powodu tekst główny oddany został antykwą, zaś partie łacińskie kursywą. Warto odnotować, że jedynymi „obcymi” elementami w rękopisie są trzy własnoręczne podpisy urzędników ziemskich: Bartłomieja Suchorzewskiego, Prokopa Broniewskiego

\footnotetext{
${ }^{28}$ UdR. Spisy, t. 1, z. 2, s. 67.

${ }^{29}$ Tamże, s. 86. To opracowanie podaje, że Rysiński był wojskim kaliskim w od 31 I 1575 do 10 IV 1577, kiedy to został mianowany na urząd kasztelana kowalskiego. Bazując na orientacyjnym określeniu chronologii wydawanego rękopisu, należałoby przesunąć okres urzędowania przez Rysińskiego na stanowisku wojskiego kaliskiego od wiosny $1571 \mathrm{r}$.

${ }^{30}$ Dostępna w sieci pod adresem $<$ http://mikmach.hg.pl/zrodla2/lepszy.html> [dostęp: 13.02.2016].
} 
i Janusza Rysińskiego (k. 309) umieszczone tuż pod ich pieczęciami odciśniętymi w wosku przez papier. Na pewno obcą dla głównej treści rękopisu jest także ręka go otwierająca (k. 300), gdzie u góry karty znajduje się napis: Act Revisorow Ziemskich | Voievodstwa Caliskiego. Pismo to nie występuje nigdzie w wydawanym źródle. Ma ono także bardziej kursywny charakter niż pismo głównej ręki. O jej odmienności może świadczyć także użycie górnej ligatury pomiędzy literami $s$ i $t$, która w tekście rękopisu nie wystąpiła ani razu, mimo że mogła mieć na to szansę (np. k. 302v iest, k. 303: stronÿ). Być może tytuł rękopisu nadany został już w archiwum koronnym po dostarczeniu rewizji, by możliwe było odróżnienie go od pozostałych materiałów archiwizowanych na zamku królewskim.

Nazwy osad oraz obiektów fizjograficznych wymienionych w źródle były w miarę możliwości normalizowane za serią „Atlas historyczny Polski: Mapy szczegółowe XVI wieku”31. Każdorazowo podawałem jednak w przypisie oryginalną transliterację każdego z nich tak, aby materiał ten był przydatny dla badań onomastycznych lub geograficzno-historycznych. $Z$ racji istnienia w sieci w pełni przeszukiwalnej mapy XVI-wiecznej Wielkopolski oraz zamieszczenia w artykule mapy obrazującej stan komór celnych i stacji mytniczych województwa kaliskiego, zrezygnowałem w niniejszej edycji z podawania dokładnej lokalizacji poszczególnych osad. Opisywano je tylko wtedy, gdy okazywało się, że dokładna identyfikacja jest niepewna. Wypadki te odnotowywano z odpowiednim komentarzem w przypisach rzeczowych.

Idąc za sugestiami dotychczasowych wydawców lustracji zrezygnowałem także z osobnego wykazu dyplomów przytaczanych przez rewizorów ${ }^{32}$. Wszystkie dane podawałem za to $\mathrm{w}$ miarę możliwości w przypisach rzeczowych odnoszących się do poszczególnych fragmentów tekstu. Skopiowanych przez rewizorów dokumentów szukałem przede wszystkim w publikowanych od końca XIX w. tomach Kodeksu dyplomatycznego Wielkopolski. Podstawową serią źródłową była jednak Metryka Koronna — kopii dokumentów poszukiwałem zarówno w odpowiednich summariuszach (Matricularum Regni Poloniae summaria), jak i nieopracowanych jeszcze tomach zamieszczonych na stronie AGAD. Wzmianki o komorach celnych i stacjach mytniczych kontrolowałem także w wydanych do tej pory Lustracjach woje-

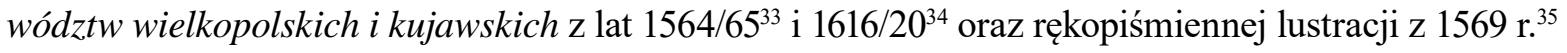

Lektura Aktu rewizorów upewnia o tym, że królewscy urzędnicy samodzielnie dokonywali wizji lokalnych. Przekonuje o tym chociażby notatka znana z Jarocina, gdzie rewizorzy podali, że „[...] dla powietrza i tam w okolicej będącego nie dojeżdżali, ale sprawę dano w Kobylinie, iż tam wielkie a nieznośne cło i więcej niż na jednym miejscu wybierają" ${ }^{36}$. Tak samo potwierdzają to wzmianki dotyczące nieokazania dokumentów urzędnikom ze względu na nieobecność właścicielii ${ }^{37}$. Obecnie niemożliwe jest wytyczenie dokładnego itinerarium rewizorów ziemskich, ponieważ nie znamy dat dziennych dokonania lustracji w każdej ze znanych nam osad. Ciężko także odtworzyć tę drogę na podstawie kolejności wymieniania poszczególnych miejscowości, gdyż w spisie często dochodzi do jej zaburzenia. Przykładowo trasa: Łagiewniki (powiat koniński) — Pyzdry (pow. pyzdrski) — Mostki (pow. koniński) — Powidz (pow. gnieźnieński) — Izdebno (pow. gnieźnieński) — Slesin

\footnotetext{
${ }^{31}$ Rejestry poborowe województwa kaliskiego w XVI wieku, red. M. Słoń, „Atlas Źródeł i Materiałów do Dziejów Dawnej Polski, 2, <www.atlasfontium.pl> [dostęp: 10.02.2016] oraz Ziemie polskie Korony w XVI w. Przestrzenna baza danych, $<$ http://atlasfontium.pl/index.php?article=korona $>$ [dostęp: 13.02.2016].

${ }^{32}$ K. Chłapowski, J. Dygdała, Prace edytorskie nad lustracjami dóbr królewskich XVI-XVIII w. po półwieczu, St. Źródł., 43, 2005, s. 166

${ }^{33}$ Lustracja województw wielkopolskich i kujawskich 1564-1565, t. 1-2, wyd. A. Tomczak, Cz. Ohryzko-Włodarska, J. Włodarczyk, Warszawa 1961-1963 [dalej: LWK 1564/65].

${ }^{34}$ Lustracja województw wielkopolskich i kujawskich 1616-1620, t. 1-2, wyd. Z. Górski, R. Kabaciński, J. Pakulski, Wrocław 1994 [dalej: LWK 1616/20].

35 AGAD, ASK XLVI 103d [dalej: Lustracja 1569].

${ }^{36}$ Akt Rew., k. 305v. O zarazie panującej w Wielkopolsce w 1571 r. pisał także Antoni Walawender: A. Walawender, Kronika klęsk elementarnych $w$ Polsce $i$ w krajach sąsiednich $w$ latach 1450-1586, t. 1: Zjawiska meteorologiczne i pomory (z wykresami), Lwów-Warszawa 1932, s. 276.

37 Akt Rew., k. 302v-305v.
} 


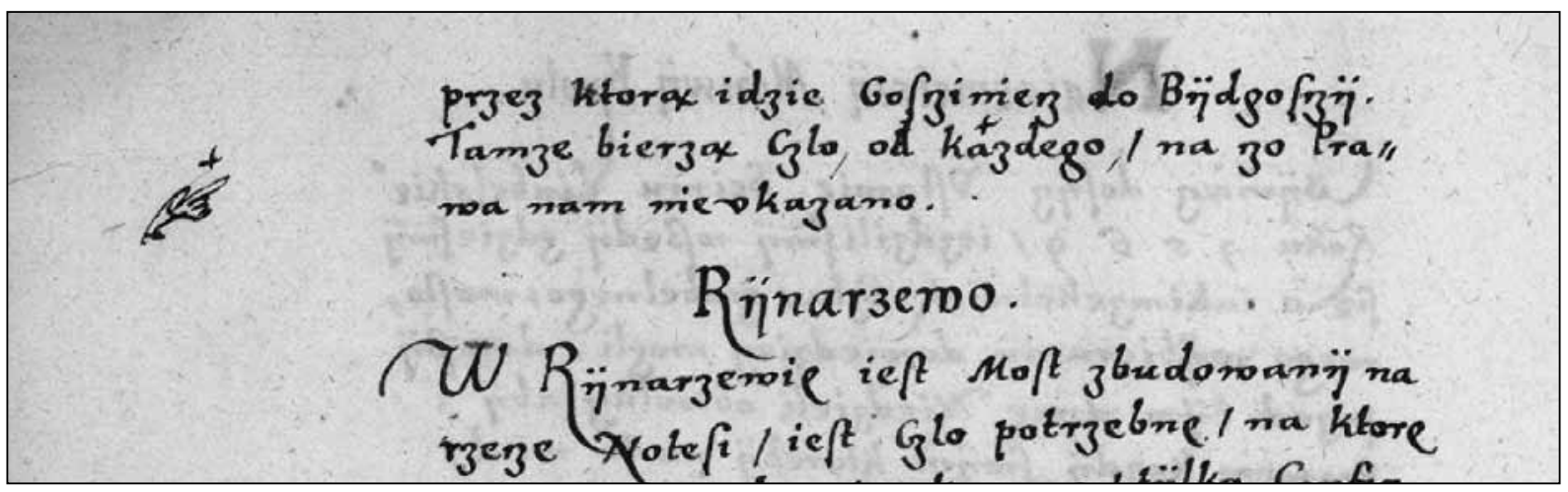

2. Fragment rękopisu przedstawiający graficzny znak ręki. Akt Rew., k. 302v

(pow. koniński) — Stawiszyn (pow. kaliski); czy dalej: Chwaliszew (pow. kaliski) — Koźmin Wlkp. (pow. pyzdrski) — Jarocin (pow. pyzdrski) — Koło (pow. koniński). Ogólny kierunek tej trasy jest jasny — z północy na południe. Być może trasa ta odzwierciedla częściowo pewną ogólnogospodarczą tendencję wzmożonego ruchu na linii północ-południe (Śląsk, Prusy Królewskie, Wielkie Księstwo Litewskie) oraz wschód-zachód (Śląsk, Małopolska, Ruś, Mołdawia). To także tłumaczyłoby — chociaż częściowo - zdecydowanie większą liczbę komór celnych i stacji mytniczych na południowych obszarach województwa kaliskiego niż w województwie poznańskim w tym okresie ${ }^{38}$.

$\mathrm{Na}$ kartach źródła nie zaobserwowano żadnych notek marginalnych poza szkicem przedstawiającym rękę z wyciągniętym palcem wskazującym na karcie 302v (il. 2). Rysunek miał zapewne służyć podkreśleniu wagi zdania, w którym rewizorzy zanotowali informację o bezprawnym pobieraniu myta przez Czarnkowskich od wszystkich osób przejeżdżających trasę Pomorze-Śląsk ${ }^{39}$. Tekst lustracji podaje:

(k. 302, wers 26)
(w. 27)
(w. 28)
(w. 29)
(k. 302v, w. 1)
(w. 2)
(w. 3)

Tur.

Na grunczie Panow z Czarnkowa widzie= lismy Mlÿn / ktorÿ zową Tur / nalezą= czy do Szubina / v ktorego iest grobla / przez ktorą idzie goscziniecz do Bÿdgosczÿ tamze bierzą czło / od kazdego / na czo pra= wa nam nievkazano.

Praktykę wskazaną w tym wypadku przez lustratorów należy rozumieć jako podkreślenie znaczącego nadużycia ze strony dosyć ważnego rodu szlacheckiego, gdyż stacja mytnicza w Turze nie powinna istnieć bez wyraźnego nadania królewskiego. Na razie nie jestem w stanie stwierdzić, jaki procent wszystkich komór celnych i stacji mytniczych istniejących w drugiej połowie XVI w. w Wielkopolsce, stanowią te znane z Aktu rewizorów. Zagadnienie to wymagałoby intensywnych poszukiwań w Metryce Koronnej, materiałach o XV-wiecznej proweniencji ${ }^{40}$. Znaczącym utrudnieniem na pewno jest brak spisów, które w sposób regularny podawałyby informacje zarówno o punktach poboru cła jak i myta ${ }^{41}$.

\footnotetext{
${ }^{38}$ Pełną listę odnalezionych komór celnych oraz punktów poboru myta w Wielkopolsce zamieszczę w rozdziale poświęconym drogom w wielkopolskim tomie serii „Atlas historyczny Polski. Mapy szczegółowe XVI wieku”.

${ }^{39}$ Lustracja w tym względzie nie odróżnia myt od ceł, nazywając wszystkie opłaty pobierane w wymienionych miejscowościach cłami.

${ }^{40} \mathrm{O}$ tym, jaki procent całości dochodów w monarchii Jagiellonów mogły stanowić opłaty z ceł zob. artykuł: P. Guzowski, K. Boroda, From King's Finance to Public Finance. Different Strategies of Fighting Financial Crisis in the Kingdom of Poland under Jagiellonian Rule (1386-1572), w: The Financial Crises, Their Management, Their Social Implications and Their Consequences in Pre-Industrial Times, red. G. Nigro, M. T. Bartoli, M. Boddi et al., Firenze 2016, s. 456.

${ }^{41}$ Zupełnym wyjątkiem jest spis komór z terenu województwa poznańskiego: Descriptio camerarum finitimarum contributionis quarti grossi pro Anno Domini 1583 in conventionibus particularibus ac generali Colensi laudatarum (AGAD, ASK I 124, k. 11-14). Dodatkowy spis komór celnych dla województwa poznańskiego z 1647 r. znajduje się w dodatku do arty-
} 


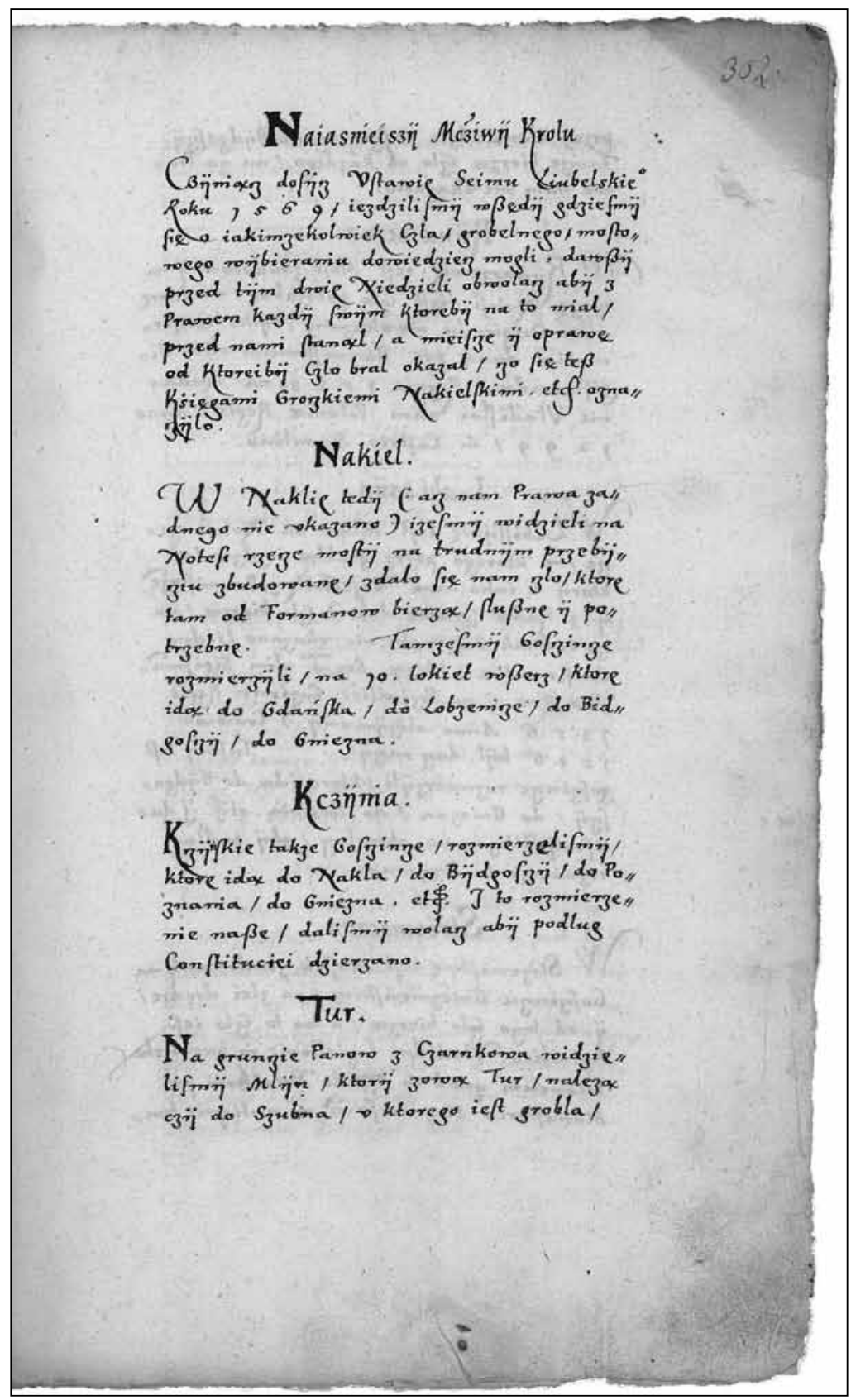

3. Pierwsza karta Aktu rewizorów, Akt Rew., k. 302

Jestem przekonany o tym, że edycja zachowanej rewizji ceł województwa kaliskiego jest wręcz niezbędna, gdyż oświetla nie tylko stan troski o skarb u schyłku monarchii jagiellońskiej, ale także może posłużyć do prac nad rekonstrukcją sieci drogowej XVI-wiecznej Wielkopolski, gdyż jedyna do tej pory praca Stefana Weymanna zdaje się już być mocno zdezaktualizowana i nie odpowiada wymogom dzisiejszej geografii historycznej. Dane zawarte w tym źródle nie tylko w istotny sposób poszerzają naszą wiedzę o funkcjonowaniu urzędów lokalnych w Koronie u progu czasów nowożytnych, ale także pokazują stan ważniejszych arterii komunikacyjnych w województwie kaliskim,

kułu Stefana Weymanna: S. Weymann, Zagadnienie dróg, s. 252-253 (Komory y przykomorki na pograniczu do dawnych nowo przyczynione, okrom komor głownych in Regno z dawna ustanowionych) wraz z mapą. 
ich zmienność wywoływaną rozmaitymi czynnikami społecznymi oraz przyrodniczymi. Niniejsza edycja zachęca także do przedstawienia pewnych dalszych postulatów badawczych, do których na pewno należy zaliczyć opublikowanie drukiem Expeditiów grobelnych, mostowych i brukowych wedle okazowania przywilejów z ruskich ziem na sejmie warszawskiem ${ }^{42}$ oraz $O$ mytach mostowych $i$ grobelnych, które biora $w$ rozmaitych wsiach $w$ ziemiach ruskich, a nie okazowały przywilejów na sejmie warszawskiem ${ }^{43}$. Na pewno należałoby zająć się także funkcjonowaniem ceł i myt w monarchii jagiellońskiej w kontekście ich rozmieszczenia geograficznego oraz wpływu uzyskiwanych z nich dochodów na kształtowanie uposażenia urzędów ziemskich oraz skarbu koronnego w średniowieczu i wczesnej nowożytności ${ }^{44}$. Osobnym postulatem byłoby także zastanowienie się nad sposobami wydania zachowanych rachunków komór celnych ${ }^{45}$. Być może najlepsza była edycja elektroniczna podobna do publikowanych obecnie rejestrów poborowych z drugiej połowy XVI wieku, ze względu na duże zbieżności w charakterze i układzie tych źródeł ${ }^{46}$.

b.m.w., spisany pomiędzy 20. kwietnia a 20. czerwca 1571

Lustratorzy królewscy: podkomorzy Bartłomiej Suchorzewski, chorąży Prokop Broniewski, wojski Janusz Rysiński dokonuja rewizji komór celnych i stacji mytniczych oraz rozmierzenia gościńców na obszarze województwa kaliskiego na podstawie uchwat sejmu lubelskiego 1569*.

Or.: Archiwum Główne Akt Dawnych w Warszawie, Metryka Koronna, dz. XVIII Lustracje, sygn. 4., k. 300309; tytul: Act rewizorów ziemskich województwa kaliskiego [k. 300]. Papier: 20,5 x $32 \mathrm{~cm}$, zachowany w dobrym stanie, bez znaczacych uszczerbków. Na stronach 301, 303, 305, 307 i 309 znajduje się znak wodny w formie herbu Tępa Podkowa. Ostatnia karta lekko wygnieciona z niewielka dziura pośrodku; na jej dole odciśnięte w wosku przez papier na sklejce, o wymiarach $18 \times 3 \mathrm{~cm}$, trzy pieczęcie herbowe przedstawiajace kolejno: herb Zaremba z inicjatami BS i PK po prawej oraz lewej heraldycznie stronie klejnotu (B[arttomiej] $\boldsymbol{S}$ [uchorzewski] P[odkomorzy] K[aliski]); kolejny to herb Leliwa prawdopodobnie z inicjałami PS; trzecia pieczęć herbowa nieczytelna - prawdopodobnie Leszczyc.

Lit.: K. Buczek, Wstęp historyczny, w: Lustracja dróg województwa krakowskiego z roku 1570, wyd. B. Wyrozumska, Wrocław-Warszawa-Kraków 1971, s. XVI-XVII.

\footnotetext{
42 AGAD, tzw. Metryka Litewska, dz. IV B, ks. 7, k. 406-415.

43 Tamże, k. 412v-415.

${ }^{44}$ P. Guzowski, K. Boroda, Form King's Finance to Public Finance, s. 451-470.

45 Przykładowo w Poznaniu zachowały się rachunki komór celnych w Międzyrzeczu, Wschowie, Kębłowie oraz Skwierzynie. Archiwum Państwowe w Poznaniu, Rachunki wielkopolskich komór celnych, sygn. C1-C11. Pewne materiały np. dla komory Częstochowskiej zachowały się w AGAD w Zbiorze Dokumentów Papierowych. Zob. H. Samsonowicz, Handel na pograniczu polsko-śląskim w świetle danych komory celnej w Częstochowie z 1584 r., Kwart. Hist., 99, 1992, z. 4, s. 3-16. O rachunkach komór celnych przechowywanych w Krakowie zob. J. Małecki, Krakowskie księgi celne i problem ich wydania, Kwart. HKM, 9, 1961, z. 2, s. 251-273.

${ }^{46}$ Por. M. Słoń, Digitale Edition der Ausheberregister aus der Wojewodschaft Kalisch des 16. Jahrhunderts, w: Editionswissenschaftliches Kolloquium 2010. Zahlen und Erinnerung von der Vielfalt der Rechnungsbücher und vergleichbarer Quellengattungen, red. H. Flachenecker, J. Tandecki, J. Kopiński, Publikationen des Deutsch-Polnischen Gesprächskreises für Quelleneditionen, t. 5, Toruń 2010, s. 393-405; M. Gochna, Elektroniczna edycja rejestrów poborowych województwa kaliskiego z drugiej połowy XVI w., „Studia Geohistorica”, 2, 2014, s. 143-150.
}

* Wydanie źródła zostało skonsultowane z dr. Mariuszem Leńczukiem z Instytutu Języka Polskiego PAN w Krakowie, któremu składam w tym miejscu serdeczne podziękowania za cenne uwagi filologiczne i edytorskie. 
[k. 302] ||Najjasniejszy Miłosciwy Królu\|, czyniąc dosyć ustawie sejmu lubelskiego roku 15697, jeździlismy wszędy, gdziesmy się o jakimżekolwiek cła, grobelnego, mostowego wybieraniu dowiedzieć mogli, dawszy przed tym dwie niedzieli obwołać, aby z prawem każdy swym, któreby na to miał, przed nami stanął, a miejsce i oprawę, od którejby cło brał, okazał, co się też księgami grodzkiemi nakielskimi etc. oznaczyło.

\section{Nakiel $^{48}$}

W Nakle tedy, acz nam prawa żadanego nie ukazano, iżesmy widzieli na Notesi ${ }^{49}$ rzece mosty na trudnym przebyciu zbudowane. Zdało się nam cło, które tam od formanów bierzą, słuszne i potrzebne a-...- Tam żesmy gościńce rozmierzyli na 10 łokiet wszerz, które idą do Gdańska, do Łobżenicy ${ }^{50}$, do Bydgoszczy, do Gniezna.

\section{Kcynia $^{51}$}

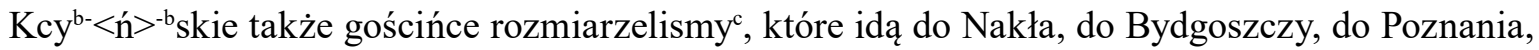
do Gniezna etc. i to rozmierzenie nasze dalismy wołać, aby podług konstytucyjej ${ }^{52}$ dzierżano.

\section{Tur}

Na gruncie panów z Czarnkowa ${ }^{53}$ widzielismy młyn, który zową Tur ${ }^{54}$, należący do Szubina, u którego jest grobla, [k. 302v] przez którą idzie gościniec do Bydgoszczy. Tamże bierzą cło od ${ }^{\mathrm{d}}{ }^{\mathrm{k}} \mathrm{kzz}_{\mathrm{dego}}{ }^{\mathrm{d}}$, na co prawa nam nie ukazano.

\section{Rynarzewo ${ }^{55}$}

W Rynarzewie jest most zbudowany na rzece Notesi, jest cło potrzebne, na które nam oryginału nie ukazano tylko konfirmacyją ${ }^{56}$ daną per serenissimum olim Sigismundum Regem $1523^{57}$ na nadanie Vladislai olim Poloniae Regis anno 1299 in castris Scomlino ${ }^{58}$.

\section{Łabiszyn ${ }^{59}$}

W Łabiszynie jest młyn na Notesi rzece, u którego przez groblą jeżdżą, od który ${ }^{60}$ [s], jako nam urzędnik z burmistrzem i z radą sprawę dali, cła bierzą, na co jednak oryginału nie ukazano

a-a Puste miejsce w rękopisie.

b-b Litera nadpisana nad słowem, wciśnięta pomiędzy „y” a „s” już po napisaniu nazwy powiatu.

c Można także odczytać: rozmiarzelismy.

d-d Słowo zapisane pogrubionym pismem, dodatkowo nad nim znajduje się krzyżyk „,+, który wiąze je z wyrysowana na boku karty ręka z palcem wskazującym, zob. il. 3.

47 Zob. przyp. 5.

48 Cto wymienione w LWK 1616/20, s. 357. Chodzi tu o Nakło.

49 Tu i dalej chodzi o Noteć. Zob. przyp. 3.

${ }^{50}$ Or. Lobzenicze.

${ }^{51}$ Or. Kczÿnia.

${ }^{5} \mathrm{Or}$. constituciei.

${ }^{53}$ Wg rejestrów poborowych okolice Szubina należaly do Czarnkowskich zob. AGAD, ASK I 4, k. 745v, 750v, 591.

${ }^{54}$ Mlyn wymieniony jako osobna jednostka osadnicza w rejestrze poborowym z $1583 \mathrm{r}$. (AGAD, ASK I 4, $k$. 743v) w parafii Samoklęski o trzech kołach walnych i jednej stępie.

${ }_{55}$ Or. Rÿnarzewo.

56 Or. confirmatia.

${ }^{57}$ Reg. MRPS, t. 4, nr 13665; kop. AGAD, MK 36, k. 335-336a.

${ }^{58}$ KDWlkp., t. 2, nr 825. Władysław Lokietek mylnie określony przez XVI-wiecznego pisarza królem. W oryginalnym dokumencie występuje jako: Wladislaus, Dei gratia dux regni Polonie et dominus Pomeranie, Cuiavie, Lancicie ac Siradie.

${ }^{59} O r$. Labiszÿn.

${ }^{60}$ Powinno być: którego. 
jedno konfirmacyją ${ }^{61}$, którą serenissi $<m u s>$ olim Sigismundus Rex, na przywilej Cazimiri Regis 1356 anno otrzymany, Cracouiae $1546^{62}$ był dać raczył. ${ }^{\mathrm{e}}-{ }_{-.}{ }^{-\mathrm{e}}$ Tusmy też gościńce rozmierzyli, które idą do Bydgoszczy, do Gniezna, do Torunia etc. i dalismy woźnemu obwołać, aby podług rozmierzenia trzymano.

\section{Strzemeszno ${ }^{63}$}

W Strzemesznie jest mostek zbudowany na gościńcu gnieźnieńskim, na złej drodze, i od tego cło bierzą, a na to cło jest przywilej Vladislai Jagiellonis in haec verba: teloneum quod in oppido Velathow ${ }^{64}$ pro monasterio Strzemesnensi ab antiquis tem[k. 303] poribus solvebatur transferrimus in Strzemessno. Praeposito ibidem et eius conventui plenam et liberam potestatem dantes huiusmodi teloneum in oppido Strzemeszno recipiendi et exigendi modo et consuetudine quibus hoc ipsum teloneum antiquitus in oppido Velatow solvebatur $1388^{65}$. A tego przywileju approbacyja ${ }^{66}$ jest per serenissimam et Sacram Maiestatem Vestram Petricoviae anno $1567^{67}$ dana. Ea insuper adiecta conditione, ut abbatibus et conventui in posterum omnes mercatores, vectores aliosque tale teloneum Strzemesense declinantes liceat arestare.

\section{Gniezno}

W Gnieźnie nam dał sprawę urząd grodzki, burmistrz i rada, iż od pana starosty żyd cło bierze i prawo ma, wszakże nam ani prawa, ani mieśca nie ukazano, iż snaś ten żyd na ten czas chorował, cosmy w księgi tamże grodzkie wpisać dali ${ }^{68}$, gościńce też na wszytki strony rozmierzywszy i obwołać dali.

\section{Konin}

Tam nam ukazano przywilej Waszej K[rólewskiej] M[ości], naszego miłościwego pana pod datą Varsoviae feria quinta post Purificationis Mariae [3 II] 1564. A quolibet equo currum trahente solidum unum a soluto equo, bove, vacca et quidem a singulis tres denarios ab unoquoque autem minorum armentorum denarios $d u o s^{69}[\mathbf{k . 3 0 3 v}]$. Tusmy też gościńce rozmierzyli, które idą do Krakowa, do Kalisza, do Torunia etc.

\footnotetext{
e-e Puste miejsce w rękopisie.

${ }^{61}$ Or. confirmatią.

${ }^{62}$ Dokumentu nie odnaleziono w MK. Nieznany jest także wymieniony dokument Kazimierza Wielkiego z 1356 r.

${ }^{63}$ Chodzi o Trzemeszno.

${ }^{64}$ Chodzi o Wylatowo.

${ }^{65}$ KDWlkp., t. 3, $\mathrm{nr} 1876$.

66 Or. approbatia.

${ }^{67}$ Dokumentu nie odnaleziono.

${ }^{68}$ Praktyka ta byla niezgodna z konstytucja sejmu piotrkowskiego z 1565 r. VC, t. 2, vol. 1, s. 170. Por. LWK 1564/65, t. 1, s. 273: Ukazali też kwit dworzanina JKM: Ja Jan Olssewski, dworzanin JKM i jurgieltnik, wyznawam tym samym kwitem, iżem wziął od Izaaka Czicza, Żyda z Gniezna i arendarza cła gnieźnieńskiego, zł 50 monety i liczby pol. jurgieltu, mnie na cle gnieźnieńskim od JKM danego i darowanego, z której sumy ja tego to przerzeczonego celnika albo arendarza kwituję niniejszem listem i wolnym czynię, czego dla lepszej pewności pieczęć swą przykładam. Dan w Lublinie, die ostatecznego oktobra, anno 1563. Zob. także LWK 1616/20, s. 69.

${ }^{69}$ Pod wymieniona data dokumentu nie odnaleziono. Cto wymienione było w LWK 1564/65, t. 1, s. 217: Cła zamkowego od wina, od soli, chmielu i inszych drobnych rzeczy okrom królewskiego przychodzi do roku c.v.u. fl. 24. Cło wzmiankowane także w Lustracji 1569, k. 59v na kwote $16 \mathrm{fl}$.
} 


\section{Biała $^{70}$}

Ukazano nam tam przywilej na cło Sigismundi Regis, Lanciciae feria quinta Octava Corporis Christi $[14 \mathrm{VI}] 1515^{71}$, wydany po pieniądzu od konia. A nadano ten przywilej i cło za świadectwem burmistrza z radą kaliskiego i także konińskiego urzędu miejskiego, którzy to zeznali naonczas przed królem Zygmuntem świętej pamięci, iż grobla i most na tej wsi Białej w konińskim powiecie potrzebne są. Zatym Wasza K[rólewska] M[ość], nasz miłościwy pan, raczyłeś dać po kwartniku Varsoviae feria quinta post Martini [14 XI] $1555^{72}$.

\section{Siejuszyce ${ }^{73}$}

Tusmy widzieli list króla Zygmunta, który, aprobacyją ${ }^{74}$ dając, referuje się do jakiegoś oryginału starego. Aprobacyją ${ }^{75}$ dano w Piotrkowie feria secunda ante Purificationis Mariae [30 I] $1525^{76}$, ale w niej nie opisano po czemu brać. Widzielismy za tym mostek na miejscu suchym i przetoż się nam zda cło niepotrzebne.

\section{Lichyń $^{77}$}

Na gościńcu, który idzie z Torunia do Kalisza, jest grobla i gać. Cło się nam zda potrzebne, ale miejsce potrzebuje lepszej naprawy. Prawa nam nie ukazano, bosmy pana nie zastali ${ }^{78}$.

\section{Rudzica}

Tu jest grobla, od który ${ }^{79}[s]$ cło bierzą. Zda się słuszne i potrzebne, ale nam prawa na to nie ukazano.

[k. 304]

\section{Lubstów, quondam oppidum ${ }^{80}$}

Na gościńcu, który idzie z Lublina do Poznania gać jest, ale niszczeje, przez łęgi i błota wielkie, gdzie idzie rzeka Szczykawa ${ }^{81}$. Tu tędy, gdy dobrze naprawowano, kupcy jeżdżali a bierano od nich cła

\footnotetext{
${ }^{70}$ Or. Biala. W powiecie konińskim występuja dwie wsi nazwane Biała, położone blisko siebie. Pierwsza z nich znajdowała się w parafii Królikowo i leżała nad struga zwana Czarna. Druga zaś administracyjnie związana byla z parafią Grochowy i leżała nad strumieniem także nazywanym Biała. W wyniku analizy topograficznej tego fragmentu rewizji oraz, wspomnienia w dalszej kolejności komory celnej w Siejuszycach (Siaszycach) powiazałem geograficznie wzmiankowany punkt z Biała w parafii Grochowy tuż na granicy z powiatem kaliskim. O toponimie „biaty”, „biel”, zob. więcej w: K. Moszyński, Uwagi o słowiańskiej terminologji topograficznej i fizjograficznej oparte przeważnie na materjale białorusko-poleskim, „Archiwum Nauk Antropologicznych", 1, 1921, nr 5, s. 2-3.

${ }^{71}$ Dokumentu nie odnaleziono.

$72 J w$.

${ }^{73}$ Or. Sieiuszycze. Na mapie XVI-wiecznej Wielkopolski miejscowość ta nazwana jest Siąszycami. W tym miejscu przyjątem nazwę zgodna z treścia źródta ze względu na jedyne, jak do tej pory, potwierdzenie tej odmianki w znanym materiale źródłowym.

${ }^{74}$ Or. approbatią.

$75 \mathrm{Jw}$.

${ }^{76}$ Reg., MRPS, t. 4/2, nr 4628; kop. AGAD, MK 38, k. 177-179.

77 Or. Lichin.

${ }^{78}$ W drugiej połowie XVI w. właścicielami Lichynia byli Gosławscy. Zob. Teki Dworzaczka nr 3966 (Nr. 16 I. i Rel. Kon. 16) 1572 r.; 4207 (Nr. 18 I. i Rel. Kon. 18) 1578 r. i 4450 (Nr. 21 I. i Rel. Kon. 21) 1584 r., <http://teki.bkpan.poznan.pl> [dostęp: 10.03.2016].

79 Powinno być: której.

${ }^{80}$ Or. Liubstow. Osada przez cały XVI w. miała status parafii wiejskiej. Nie określaja jej mianem miasteczka (oppidum) ani najstarsze zachowane rejestry poborowe z lat 1507-1510, ani rejestry lat 1534-1535. Nazwana miastem w dokumencie Kazimierza Jagiellończyka z 1457 r., zob. przyp. 82.

81 Or. Sczykawa. W kartotece Pracowni Stownika Historyczno-Geograficznego Wielkopolski (Poznań) przyjęto nazwę Szczykawa. Rzeka wymieniana przez Kozierowskiego wraz z jeziorem o tej samej nazwie (S. Kozierowski, Badania nazw
} 
od wozu formańskiego i kupieckiego po czterzy pieniądze, a [od] konia albo wołu, kto do targu wiódł, brano od niego po pieniądzu za przywilejem Kazimirza pod datą $1457^{82}$. Ale iż tego cła sąsiad Głęboc$\mathrm{ki}^{83}$ połowicę miał, prze niezgodę zaniechał naprawiać drogi na starym miejscu i dla tej ich niezgody, a nie naprawowania drogi i mostu, formani tamtędy już natenczas nie idą. A chocia się obrócili tamże od starego gościńca ćwierci mile, między Łagiewnikami a Bielewem, gdzie ten to Głębocki z Gosławskim zmówiwszy się, zabudowali inszy most, acz też nie dobry, wyprawiwszy sobie oba cło u króla Zygmunta $1530^{84} \mathrm{i}$ bierzą je. Jednak iż się szlachta niemało, która tam na tym ostrowie mieszka, skarży, że nie mogą do powiatu swego konińskiego przejeżdżać, zatym dawnego gościńca na Lubstowie spustoszeniem, kędy z dawna jeżdżali, zdało się nam to Waszej K[rólewskiej] M[ości] naszemu miłościwemu panu przy tym oznajmić, ażeby to po staremu naprawowano, gdyż tego pospolity człowiek potrzebuje.

\section{Lagiewniki ${ }^{85}$}

Na gościńcu, który idzie z Lublina do [k. 304v] Poznania jest gać zła, niedobrze naprawiona przez błota wielkie, bagniste i lgnące, przez które idzie rzeka Szczykawa. Cła bierzą od konia po trzy pieniądze, a od wołu po pieniądzu podług listu króla Zygmunta sławnej pamięci pod datą $1530^{86}$, na którym jednak prawie to stoi napisano, iż most miał być dobrze budowany.

$$
\text { Pyzdry }{ }^{87}
$$

Tu ukazano nam list Cazimiri tercii $1553^{88}$ [s] otrzymany, a jest cło u kasztelana ${ }^{89}$ biechowskiego i wójt pyzdrski też osobnie na się cło bierze, a na nie prawa nie ukaza $1^{90}$. Rozmierzylismy gościńce, które idą do Poznania, do Gniezna, do Torunia, do Bydgoszczy, do Jarocina, do Kalisza, do Stawiszyna, do Konina etc.

\section{Mostki wieś}

Jest tu gać naprawiona i przejazd, natenczas gdysmy oględowali dobry, ale nam sprawę dano, iż z wiosny bywa zły przejazd i dlategoż gać naprawują i cło bierzą po pieniądzu od konia. A nadano to cło ziemianinowi za posługę na wojnie moskiewskiej uczynioną, jako o tym list Sigismundi Regis Cracoviae feria quinta ante Oculi [4 III] $1518^{91}$ dany obmawia.

topograficznych na obszarze dawnej zachodniej i środkowej Wielkopolski, t. 2, Poznań 1922, s. 392), przeptywa m.in. przez. grunta parafii Mąkolino, potem Lubstowo Wielkie - Małe oraz Racięcice, będac doplywem Wiercicy. Nazwa pochodzi od apelatywu ,szczyk” oznaczającego 'młoda trawę na wiosnę' i/lub 'delikatna trawę rosnaca na błotach' (Stownik języka polskiego, t. 6, red. J. Karlowicz, A. Kryński, W. Niedźwiedzki, Warszawa 1909, s. 595). Zob. także E. Wolnicz-Pawłowska, Nazwy wodne dorzecza Warty od źródel do ujścia Prosny, Warszawa 2006, s. 348, por. z Elektroniczny słownik hydronimów Polski, <http://eshp.ijp-pan.krakow.pl/search/results/337603>, [dostęp: 10.03.2016].

${ }^{82}$ Dokumentu nie odnaleziono w MK 11. Dostępny jest w XVIII-wiecznym odpisie w: AGAD, Archiwum Publiczne Potockich 304, k. 127-127v.

${ }^{83}$ W drugiej połowie XVI wieku ze spisów podatkowych znani sa Serafin i Stanisław Gtęboccy. Obydwaj występują jako płatnicy (wraz z Katarzyna Glębocka) ze wsi Lubstowo Mate w latach 1564-1581. Zob. AGAD, ASK I 5, 795; ASK I 13, 17, $162 v, 232 v, 1397$ i ASK I 3, 610v.

${ }^{84}$ Przywilej wydany z data 10 III 1530. Reg. MRPS, t. 4/l, nr 5543; kop. AGAD, MK 44, k. 461-461v.

${ }^{85}$ Or. Lagiewniki. Na obszarze XVI-wiecznego województwa kaliskiego znajdowało się sześć osad o nazwie Łagiewniki. Na podstawie kontekstu przestrzennego i wymienienia we wcześniejszej zapisce Lubstowa zidentyfikowano osadę Lagiewniki jako położona w parafii Lubstowo Małe.

${ }^{86}$ Zob. przyp. 84.

87 Or. Pÿzdrÿ.

${ }^{88}$ Mylnie podano datę 1553 zamiast 1453.Dokument wystawiony z data 21 I 1453. Reg. MRPS, t. 1, nr 170; kop. AGAD, MK 10, k. 99-99v

89 Or. castellana.

${ }^{90}$ Ustanowione clo mostowe, zob. LWK 1616/20, s. 54.

${ }_{91}$ Dokumentu nie odnaleziono. 


\section{Powidz}

Tu nam okazan [był] przywilej Kazimierza króla pod datą in Calisz 1362 ${ }^{92}$, w którym przywileju, nadawając plebanowi powidzkiemu dochody inne, też decimum de[k. 305]narium telonei nadano, skąd się znaczy, iż już przed tym tam to cło było.

\section{Izdebno}

Tu ma ziemianin cło od króla Zygmunta nadane po pieniądzu od konia, a od dziesiąci wołów pół grosza, które cło, iż mu się zda małe względem kosztu, a naprawy nie chce naprawować. I wręczał nam list. Ale iż my widziemy, iż to miejsce ma przejazd zły na wielkim gościńcu poznańskim, gnieźnieńskim etc., a naprawy niemałej potrzebuje, zda się nam, żeby żaden skwierk ludzki nie był. Chociażby mu się przydało cła względem kosztu nieco więcej, to jest od konia, od wołu po kwartniku, ażeby już za takim nadaniem był powinien prawie dobrze podług potrzeby naprawować.

$$
\text { Ślesin }{ }^{93}
$$

Cło tu bierzą dwoje: jedno na kasztelana ${ }^{94}$, drugie na biskupa, na co ludzie skwierczą, bo przejazd ${ }^{95}$ jest dobry, a nie potrzebuje naprawy. Jakoż też nam i prawa żadnego na nie nie ukazano.

\section{Stawiszyn ${ }^{96}$}

Tu cło bierzą troje: królewskie pan celnik, zamkowe dzierżawca i miejskie. Na żadnesmy prawa nie widzieli, chociasmy się tego u burmistrza domawiali.

\section{Morawin}

Tusmy widzieli groblą, na której jest staw i młyn. Bierzą cło, ale nie powiedziano [k. 305v] po czemu, od czego ani prawa ukazano.

\section{Koźminiec $^{97}$}

Tu cło bierzą, ale jeszcze przed Jagiełłem od Kazimirza Wielkiego nadane ${ }^{98}$.

\section{Kamień}

Jest tu grobla, na której staw i młyn. Mamy sprawę, iż cło bierają, alesmy się dopytać nie mogli po czemu. Urzędnik powiedział, że już nie bierzą. Prawa nam nie ukazano.

\section{Koryta $^{99}$}

W Korytach, wsi ziemiańskiej, bierzą cło odolanowskie. A tę sprawę mamy, iż to cło odolanowskie bierzą w pięciorę, to jest w Odolanowie, w Sulimierzycach, w Korytach, w Zduniech i w Chwalczewie $^{100}$. Listusmy nie widzieli, ale tak iszczą ludzie, że stare cło jest. Tylko na to ludzie skwierczą, iż dalej bierzą od Odolanowa niż w mili, a ktemu iż nie na jednym miejscu, snaś inaczej niż przywilej brzmi $^{101}$.

${ }_{92}$ KDWlkp., t. 3, $\mathrm{nr} 1550$.

93 Or. Slieśin.

${ }^{94}$ Or. castellana.

95 Pierwotnie pisarz napisat: przyjazd, nadpisat jednak litere „e” nad „,y”.

96 Or. Stawiszÿn.

97 Or. Kozminiecz. Chodzi o Koźminek, położony w powiecie kaliskim nad Swędrwia.

${ }_{98}$ KDWlkp., t. 2, nr 1618.

99 Or. Korÿta.

100 Or. Chfalczewie.

101 Przywileju na cto odolanowskie nie odnaleziono. 


\section{Koźmin $^{102}$}

Tusmy nie widzieli listów żadnych, ani od czego by brano, że pana nie było, ale bierzą cło.

$$
\operatorname{Jarocin}^{103}
$$

Do Jarocinasmy dla powietrza i tam w okolicej będącego nie dojeżdżali, ale sprawę dano w Kobylinie, iż tam wielkie a nieznośne cło i więcej niż na jednym miejscu wybierają.

[k. 306]

$$
\mathrm{Koło}^{104}
$$

W Kole ukazali mieszczanie list od Waszej K[rólewskiej] M[ości] Warszoviae in conventione generali $1557^{105}$ za świadectwem rewizorów ${ }^{106}$ dany na takie cło, aby za naprawę aggerum, pontium, litostratorum od formańskich i kupieckich wozów wielkich, naładowanych po pół grosza, a od mniejszych po kwartniku, a także też od pary wołów, od pary koni, któreby ku sprzedaniu gnano, kwartnik czasy wiecznymi brali. A dobrze to wszytko oprawować mają pod utraceniem cła.

\section{Pawłowo ${ }^{107}$}

U Jutrosina na Pawłowie bierzą cło nowe. Od każdego konia zaprzężonego po kwartniku, od Polaków i od Ślęzaków, gdy albo z Polski do Śląska, albo ze Śląska do Polski jadą. Dan na to przywilej od Waszej K[rólewskiej] M[ości] naszego miłościwego pana Varszoviae 20 Aprilis $1571^{108}$. Ale przed nadaniem byli rewizormi ${ }^{109}$ generosi Jacobus Rokosowski et Stanislaus Bniński Posnaniensis, et Lucas Rydziński Wschouensis iudices. ${ }^{\mathrm{f}} \cdot . .{ }^{-\mathrm{f}}$ My gdysmy tam byli, widzielismy, iż w suszą może bez szkody minąć mosty. Ale sprawę mamy, iż na wiosnę na rostok zły a trudny przejazd bywa. I zdało się nam, żeby zostać mogło cło bez skwierku ludzkiego, jeżliby to opatrzono, aby cła inegdy nie brano, jedno we złe drogi, gdyby mostów minąć nie możono a ktemu, aby stara droga żadnym fortelem psowana nie była.

[k. 306v]

\section{Kalisz}

W Kaliszu widzielismy przywilej Sigismundi Regis Cracouiae feria tercia post Laetare [16 III] 1518 dany ab omnibus mercatoribus et vectoribus currus aliqua merce onustos habentibus, qui per dictam civitatem in quamcunque partem iter faciant, per sex nummos in perpetuum ad usum civitatis et reparationem pontium ${ }^{110} .{ }^{\mathrm{g}-} .{ }^{-\mathrm{g}}$ Tamże drugi przywilej na cło ołobockie de data Cracouiae feria sexta ante Dominicam Iudica [19 III] 1518 po groszu a quolibet curru ${ }^{111}$. A mieszczanie kaliscy mają ten most ołobocki oprawować. A urósł ten przywilej per decretum ex controversia inter eodem cives et nobiles Sławińskie. ${ }^{\mathrm{h}} . . .{ }^{\text {h }}$ Nadto ukazano przywilej Boleslai ducis Poloniae 1264 in Kalisz ${ }^{112}$ otrzy-

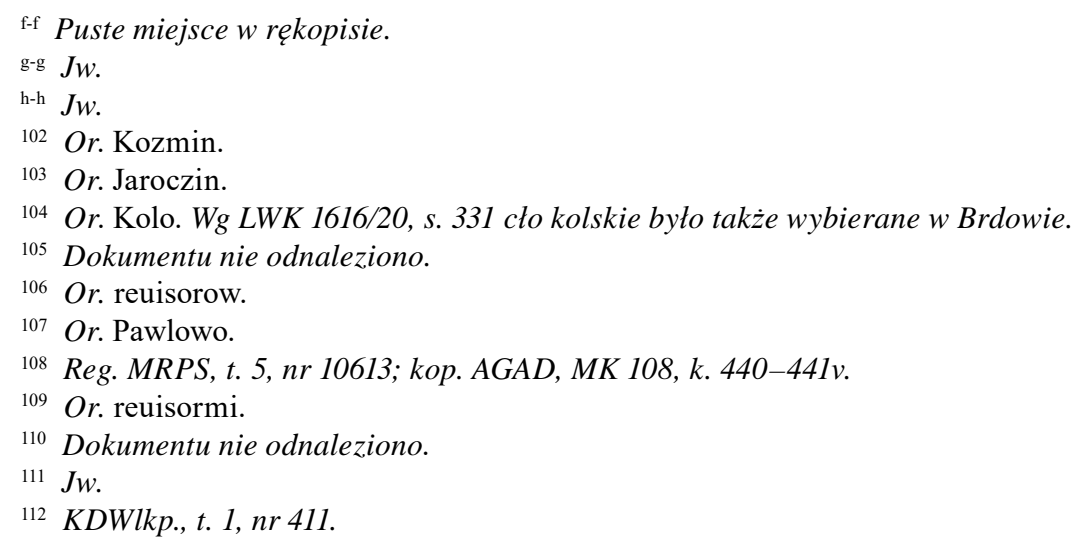


many, którym przywilejem nadano pro reformatione eiusdem civitatis de singulis curribus hospitum sal vehentium quartale salis perpetualiter i wybierają po wiertelu, nie po ćwiartce ćwierdząc $[s]$, iż tak z staradawna brano ${ }^{113}$.

$$
\text { Kobylin }{ }^{114}
$$

Tu nam ukazali mieszczanie przywilej Władysława króla Lanciciae sabbato in die Dominici Confessoris [5 VIII] $1430^{115}$ dany. Nadano im po zgorzeniu prawo majdeburskie, targi i jarmarki, tak aby każdy mógł vendere, emere, commutare et rebus dispositis vel non dispositis libere secure cessante quavis exactione redire etc. A przedsię przyznali, iż przykładem śląskich i polskich przyległych miasteczek targowego po groszu od konia bierzą; ukazali też ciż mieszczanie i drugi list [k. 307] nowy Varszouiae $1570^{116}$ otrzymany na cło takowe, aby im wolno brać a quolibet equo currui iuncto grossum unum a curru vero ipso medium grossum, a bove quolibet per denarios sex, a vervece, porco per denarios tres, cum conditione reparationis aggerum et pontium, a wszakże nie dołożono, aby to sub amissione telonei czynić byli powinni, czego $\mathrm{w}$ innych liściech dokładano potrzebnie. ${ }^{\mathrm{i}-\ldots}{ }^{-\mathrm{i}} \mathrm{Chcąc}$ potym widzieć situm locorum widzielismy dwie groble na różnych miejscach, które od miasta idą nie nazbyt długie już ubrukowane, których jednak jeszcze nie dokończono. Wszakże powiedzieli mieszczanie, że i grobel nadstawić i mosty zbudować chcą, na których groblach my widzielismy, że stawy są dobre, z których iż od jednego do drugiego rowy bito, wodę przywodząc. Mieszczanie przez one rowy rozumieją, że mosty mają być potrzebne, wszakże ich jeszcze natenczas nie było. ${ }^{j-. .}{ }^{-j} \mathrm{Zda}$ się nam tedy, niemało skwierk być, dosyć by po kwartniku nawięcej od konia zaprzężonego, gdy z towarem wozy idą, a od woza nałożonego po pół grosza. A to żeby tylko od Ślęzaków, przestrzegając skwierków w Koronie, a od wołów, gdyby kupcy gnali, po kwartniku, nie po szelągu, jako sobie uprosili, od skopów, od wieprzów aby nic nie brano.

Gościńce przez Kobylin do wszytkiej Korony od Wrocławia i od inszych miast śląskich idą, które podług konstytucyji ${ }^{117}$ rozmierzywszy obwołać jesmy dali.

\section{Osiek Mały ${ }^{118}$}

\section{$[$ k. 307v]}

Strony tej wsi dana nam jest protestacyja ${ }^{119}$ od pana biechowskiego kasztelana ${ }^{120}$, jako od dziedzica in haec verba:

Moi łaskawi panowie rewizorowie W[asze] M[ości] opowiadam, iż ja [ze] strony swej przez wieś i dziedzinę swą Małego Osieka dopuścić nie mogę tak szeroko wymierzyć drogi jako jest konstytucy$\mathrm{ja}^{121}$, dlatego, iż są role barzo lipkie na tej dziedzinie, których ról nie tylko tę szerokość i dobrze więcej formani zawsze psują, i gać, którą ludzie we wsi dla przejazdu swego sobie czynią zawsze pokażą, ku szkodzie mojej i ubogich poddanych moich, której szkody ja przestrzegając formanom, co idą od Koła ku Toruniewi et e contra, pozwalam jeździć na Budzisław, też majętność moję, gdzie im i bliżej i lepsza droga, bo więcej borem niż polem. A w polu droga według konstytucyji ${ }^{122}$ wymierzona będzie.

\footnotetext{
i-i Puste miejsce $w$ rękopisie.

j-j $J w$.

${ }_{113}$ Cto potwierdzone także w LWK 1564/65, t. 1, s. 211 na sumę 11 fl. $i$ w Lustracji 1569, $k$. 55v na tę samą kwotę.

114 Or. Kobÿlin.

${ }_{115}$ KDWlkp., t. 9, $\mathrm{nr} 1243$.

116 Dokumentu nie odnaleziono.

117 Or. constituciei.

118 Or. Osiek Malÿ.

119 Or. protestatia.

120 Or. castellana.UdR. Spisy, t. 1, z. 2, s. 34. Petnit urząd od 5 VI 1568 do 20 VI 1571.

121 Or. constitucio.

122 Or. constituciei.
} 
I proszę, aby tę moję protestacyją ${ }^{123} \mathrm{~W}$ [asze] M[ości] do akt swych wpisali i tę drogę, którą wydawam przez inszy grunt swój, przez woźnego publikować dopuścili.

Stanisław Wysocki

ręką własną

Alesmy publikacyją tej drogi do Waszej K[rólewskiej] M[ości] Pana swego Miłościwego nauki odłożyli, to przyznawając, iż lepsza droga formanom na Budzisław niż na Osiek.

\section{Wyszkowy ${ }^{124}$ et Twardowo}

W Wyszkowach cło in haec verba jest na nie przywilej ${ }^{125}[\mathbf{k} .308]{ }^{\mathrm{k}-S i g i s m u n d u s ~ A u g u s t u s ~ D e i ~ g r a t i a ~}$ rex Poloniae, magnus dux Litwaniae, Russiae, Prussiae, Mazouiae etc. dominus et haeres ${ }^{-k}$. Significamus literis praesentibus quorum interest universis, humiliter nobis supplicatum esse pro parte nobilis Martini Wyszkowski, qui literas sibi deperditas quereretur super pontale teloneum seu vectigal, quod ob factum et quotidie reficiendum pontem circa villas Wyszkowy ${ }^{126}$ et Twardowo ${ }^{127}$ strenuo Martino de Magnuszewicze praedecessori eius a divo olim Cazimiro avo nostro desideratissimo concessum donatumque erat, illo nempe deperditas tempore quo isti, qui vectigalia et telonea exigunt, praesertim ex Maiore Polonia ab magnifico Andrea comite a Gorka castellano Posnaniensi et Maioris Poloniae ${ }^{1-}$ generali capitaneo-1, $^{-1}$ secundum laudum in comitiis generalibus laudatum cittati fuerant reposituri iura et privilegia quorum nomine telonea ipsa exigerent, quod quidem non secus factum esse vel ex eo potissimum comperti sumus, quod transcriptum illud ipsum ius privilegiumque repertum in regestro illic cancellariae nostre esset, ubi omnia, omni illo tempore producentium privilegia de verbo ad verbum ${ }^{\mathrm{m}}$-fideliter ${ }^{\mathrm{m}}{ }^{\mathrm{m}}$ sunt conscripta nobisque per capitaneum Maioris Poloniae transmissa. Supplicatio autem eiusmodi senatorum regni nostri pro Martino Wyszkowski fuit, ut similiter iterum ius privilegiumque super illud ipsum vectigal secundum literarum priorum textum ex gratia nostra regia transcribi ${ }^{128}$ illi sineremus ac veluti denuo ${ }^{\text {n- }}$ illi denиo ${ }^{\text {-n }}$ concederemus quando quidem nulla spes priorum literarum illi in tumultu illo deperditarum rehabendum sit relicta. Literarum autem illarum de verbo ad verbum tenor talis est.

Cazimirus dei gratia rex Poloniae etc. Intelligendo ex literis consulum Calisiensium [k. 308v] negociatoribus, institoribus et salis ductoribus difficilem ac periculosum fuisse transitum per fluvium Liutinia $^{129}$ circa villas Wyszkowy et Twardow haereditarias strenui Martini de Magnuszouicze ad supplicationem ipsorum civium, qui ob ingentes sumptus aggerum et pontium ultro se obtulerunt condignum vectigal daturos ab omnibus curribus quibusvis mercibus oneratis per sex denarios et a quolibet salis curru quartam partem unius quartalis salis in haereditate Wyszkowo ipsi Martino ratione telonei alias mostowe per dictos pontes duntaxat exigendi et percipiendi dedit et instituit. Ea tamen conditione, quod praefatus Martinus cum suis successoribus ad reparationem dictorum pontium et aggerum debet

\footnotetext{
k-k Kop. brak tytulatury.

${ }^{1-1} \mathrm{Kop}_{1}$. capitaneo generali.

$\mathrm{m}-\mathrm{m} K o p_{1}$. sunt fideliter.

n-n Brak w Kop

123 Or. protestatią.

124 Or. Wyskowy.

${ }^{125}$ Przywilej zachowany jest $w$ trzech kopiach. Pierwszej - najbliższej oryginałowi pochodzacej z MK; drugiej znanej $z$ Aktu Rew. oraz trzeciej zachowanej w AGAD w Archiwum Publicznym Potockich w księdze o sygnaturze 304. Ostatnia $z$ nich ma charakter XVIII-wiecznego całościowego odpisu XVI-wiecznej księgi zawierajacej kopie dokumentów okazywanych lustratorom królewskim podczas rewizji lat 1564-1565. Ze względu na charakter edycji zdecydowatem się na podawanie różnic pomiędzy wydawanym rękopisem a kopia dokumentu znana z MK oznaczona w przypisach jako „Kop,”. Reg. MRPS, t. 5, nr 1011; Kop . AGAD, MK 78, k. 370-371v. W związu z tym pominątem wymienianie w przypisach różnic pochodzacych z XVIII-wiecznej księgi.

${ }^{126} \mathrm{Kop}_{1}$. Wiskowi.

${ }^{127}$ Kop $p_{1}$. Thwardow.

${ }^{128} \mathrm{Kop}_{1}$. transscribi.

${ }^{129} \mathrm{Kop}_{1}$. Luthinia.
} 
esse obligatus. Sub data Vilnae feria sexta post festa solemnis Paschae proxima [29 III] Anno Domini $M^{\circ} C_{C C C}^{\circ} X X X X V I I I^{\circ}$ [1448]. Sub relatione magnifici Hincza de Rogow Regni Poloniae vicesthesaurarii. ${ }^{0-} . .{ }^{-0}$ Nos igitur senatorum Regni in comitiis praesentibus congregatorum supplicationibus permoti, quas diligenter et humiliter apud nos pro eodem Martino fecerunt eidem ius et privilegium secundum tenorem prioris dari et scribi mandavimus damusque et concedimus praesentibus illud in omnibus suis punctis ${ }^{\mathrm{p}-}$ articulis ${ }^{\mathrm{p}}$ approbantes et roborantes atque nihilominus pronunciamus eiusmodi robur et vigorem habiturum ac si nunc primo a nobis ipsis cum totius senatu et ordinum consensu concessum datumque fuisset, eiusque vigore vectigal supra descripto modo perpetuis temporibus est percepturus sub eadem conditione superius sufficienter descripta. In cuius rei testimonium ${ }^{\mathrm{r}}$ sigillum nostrum praesentibus est subappensum ${ }^{-\mathrm{r}}$. Datum Piotrcouiae in conventione generali, feria secunda pridie festi divae Mariae Magdalenae [21 VII] Anno Domini $M^{\circ} D^{\circ} L^{\circ}[1550]$ Regni nostri XXI ${ }^{\circ}$. Więcejsmy miejsc nie oględowali, nie [k. 309] mając instrukcyji od W[aszej] K[rólewskiej] M[ości] i nie wiedząc ni od kogo dostatecznie o więcej gdzieby cło, abo mostowe, abo grobelne jakie brano.

W[aszej] K[rólewskiej] M[ości] n[aszego] M[iłosciwego] P[ana] Wierni poddani i słudzy

[tu następuja pieczęcie herbowe odciśnięte w wosku przez papier z własnoręcznymi podpisami urzędników, zob. il. 1] ${ }^{130}$
Bartłomiej Suchorzewski s-podkomorzy kaliski ${ }^{1 \mathrm{~s}}$ ręką własną

\author{
Prokop Broniewski \\ chorąży kaliski \\ ręką własną
}

\author{
Janusz Rysiński \\ wojski kaliski \\ ręką własną
}

\title{
Inspection of Customs Houses and Tollgates in the Voivodeship of Kalisz from 1571. Edition of Akt rewizorów ziemskich
}

\begin{abstract}
Summary: The mid-sixteenth century in Poland was a period of intensified work on the reinforcement of monarchic rule and the stabilisation of state finances. An enormous contribution was made by the execution of the laws movement, whose undertakings resulted in, i.a. regaining a considerable part of the illegally seized royal landed estates. In the $1560 \mathrm{~s}$ it also involved a detailed inspection of property belonging to the king. This task aimed not only at becoming acquainted with the detailed economic state of royal landed estate complexes leased by the starostas, but also at estimating the revenue they supplied. After all, the estates in question constituted one of the permanent pillars replenishing the state budget, which, apart from immense sums obtained from extraordinary taxes, included also proceeds from customs and the right to mint coins. Despite the fact that since the 1970s pertinent writings have been familiar with the 1571 inspection of customs and tolls in the voivodeship of Kalisz, preserved in the Central Archives of Historical Records in Warsaw, it was treated as an inferior source and even as outright useless for historical studies. Karol Buczek - the author of an introduction to an inspection of roads in the voivodeship of Little Poland (1570) - recognised that the fundamental object of the interests of sixteenth-century inspectors involved main roads and that this work was conducted in a slipshod manner. The same author even declared that the text of the revision does not make a great contribution to the state of research, since the customs houses and tollgates mentioned in the text were known, even if only from preserved inspections dating from the period of the execution of property. Today we may say that Buczek's opinion was overly harsh and cursory. Customs houses and tollgates were mentioned sporadically in inspections from the $1560 \mathrm{~s}$,

\footnotetext{
o-o Puste miejsce w rękopisie.

p-p Tak w Kop .

${ }^{\text {r-r }}$ Brakw Kop ${ }_{1}$.

s-s $O r$. podkomorzej kaliskiej.

${ }_{130}$ Pieczęcie wraz ze znajdującymi się pod nimi podpisami urzędników zostały oddzielone przez pisarza lekko ukośnymi liniami.
} 
but the overwhelming majority remained ignored in heretofore literature. The contents of Akt rewizorów can prove that the tour of the voivodeship (carried out upon the basis of a constitution passed by the Sejm of Lublin in 1569) was satisfactory. Despite the absence of any sort of assistance - be it only a list of customs and toll grants - the officials, i.e. the subcamerarius, the standard-bearer (vexillarius), and the tribunus managed, with the help of interviews with the local residents and own familiarity with the terrain, to travel across the entire voivodeship of Kalisz within its sixteenth-century borders and to record probably all the existing customs houses and tollgates. The source also provides much information about the emergence of main and side roads, whose course could change depending on the weather, time of year, or relations between particular neighbourslandowners. The published source is a loose-leaf volume comprising part of a larger book containing assorted inspection material - nine leafs of clean copy in one person's handwriting. It ends with the signatures of three inspectors who supervised the whole operation, and their armorial seals. A major part of Akt rewizorów was written in Polish, and Latin was used, as a rule, for all passages originating from documents confirmed by the inspectors. A critique of the text made it possible to precisely establish the date of the document's origin (20 April - 20 June 1571).

Nota o autorze: Tomas z Zw ią ze k - mgr, asystent w Zakładzie Atlasu Historycznego w Instytucie Historii im. Tadeusza Manteuffla PAN. Zajmuje się dziejami średniowiecznego i nowożytnego młynarstwa w Polsce, onomastyką oraz geografią historyczną. Pisze pracę doktorską poświęconą osadnictwu wiejskiemu w powiecie kaliskim na przełomie XV i XVI w.

Author: To mas z Z w i ą ze k - M.A. research assistent in the Department of Historical Atlas in the Tadeusz Manteuffel Institute of History of Polish Academy of Sciences. His scientific interests are the medieval and early modern milling industry in Poland and historical geography. He writes his PhD dissertation about rural settlement in Kalisz district (Greater Poland) on the turn of 15th and 16th centuries.

Instytut Historii im. Tadeusza Manteuffla PAN, Zakład Atlasu Historycznego, Rynek Starego Miasta 29/31, 00-272 Warszawa

e-mail: tzwiazek@ihpan.edu.pl

\section{Bibliografia}

Blanchard I., The Continental European Cattle Trades, 1400-1600, „The Economic History Review”, New Series, 39, 1986, z. 3, s. 437-441

Chłapowski K., Dygdała J., Prace edytorskie nad lustracjami dóbr królewskich XVI-XVIII w. po pótwieczu, St. Źródł., 43, 2005, s. 161-171

Gochna M., Elektroniczna edycja rejestrów poborowych województwa kaliskiego z drugiej połowy XVI w., „Studia Geohistorica”, 2, 2014, s. 143-150

Górska-Gołaska K., Noteś w: Stownik historyczno-geograficzny województwa poznańskiego w średniowieczu, oprac. K. Górska-Gołaska, T. Jurek, J. Luciński, G. Rutkowska, I. Skierska, red. A. Gąsiorowski, cz. 3, z. 2, Poznań 1995, s. 312-317

Guldon Z., Stępkowski L., Handel wołami w świetle rejestrów celnych komory kaliskiej z lat 1647-1654, Kwart. HKM, 26, 1978, z. 4, s. 537-542

Guzowski P., Boroda K., From King's Finance to Public Finance. Different Strategies of Fighting Financial Crisis in the Kingdom of Poland under Jagiellonian Rule (1386-1572), w: The Financial Crises, Their Management, Their Social Implications and Their Consequences in Pre-Industrial Times, red. G. Nigro, M. T. Bartoli, M. Boddi et al., Firenze 2016, s. 451-470

Lustracja dróg województwa krakowskiego z roku 1570, wyd. B. Wyrozumska, wstęp historyczny K. Buczek, Wrocław-Warszawa-Kraków 1971

Małecki J., Krakowskie księgi celne i problem ich wydania, Kwart. HKM, 9, 1961, z. 2, s. 251-273

Małowist M., Wschód a Zachód Europy w XIII-XVI wieku, Warszawa 2006

Manikowski A., Łukasiewicz J., Kaliszuk M., Cło, w: Encyklopedia historii gospodarczej Polski do 1945, t. 1, red. A. Mączak, Warszawa 1981, s. 103-105

Nowakowa J., Rozmieszczenie komór celnych i przebieg dróg handlowych na Ślasku do końca XIV wieku, Prace Wrocławskiego Towarzystwa Naukowego, Seria A, nr 43, Wrocław 1951

Pałucki W., Studia nad uposażeniem urzędników ziemskich w Koronie do schyłku XVI wieku, Warszawa 1962 
Rejestry poborowe województwa kaliskiego w XVI wieku, red. M. Słoń, Atlas Źródeł i Materiałów do Dziejów Dawnej Polski, 2, <www.atlasfontium.pl> [dostęp: 10.02.2016]

Rybarski R., Handel i polityka handlowa Polski w XVI stuleciu, t. 1: Rozwój handlu polityki handlowej, Poznań 1928

Russocki S., Myto, w: Encyklopedia historii gospodarczej Polski do 1945, t. 1, red. A. Mączak, Warszawa 1981, s. 572

Samsonowicz H., Handel na pograniczu polsko-śląskim w świetle danych komory celnej $w$ Częstochowie z 1584 r., Kwart. Hist., 99, 1992, z. 4, s. 3-16

Samsonowicz H., Przemiany osi drożnych w Polsce późnego średniowiecza, Przegl. Hist., 64, 1973, z. 4, s. 697-716

Słoń M., Digitale Edition der Ausheberregister aus der Wojewodschaft Kalisch des 16. Jahrhunderts, w: Editionswissenschaftliches Kolloquium 2010. Zahlen und Erinnerung von der Vielfalt der Rechnungsbücher und vergleichbarer Quellengattungen, red. H. Flachenecker, J. Tandecki, J. Kopiński, Publikationen des Deutsch-Polnischen Gesprächskreises für Quelleneditionen, t. 5, Toruń 2010, s. 393-405

Walawender A., Kronika klęsk elementarnych w Polsce i w krajach sasiednich w latach 1450-1586, t. 1: Zjawiska meteorologiczne i pomory (z wykresami), Lwów-Warszawa 1932

Weymann S., Ze studiów nad zagadnieniem dróg w Wielkopolsce od X do XVIII wieku, „Przegląd Zachodni”, 9, 1953, z. 2, nr 6-8, s. 194-253

Wyrozumska B., Drogi w ziemi krakowskiej do końca XVI wieku, Wrocław-Warszawa-Kraków 1977

Ziemie polskie Korony $w$ XVI w. Przestrzenna baza danych, $<\mathrm{http}$ //atlasfontium.pl/index.php?article=korona $>$ [dostęp: 13.02.2016] 